\title{
Ephemeral Heritage: Boats, Migration, and the Central Mediterranean Passage
}

\section{ELIZABETH S. GREENE, JUSTIN LEIDWANGER, AND LEOPOLDO REPOLA}

The central Mediterranean today marks one of the most active and dangerous routes for sea crossings to Europe, due in no small part to border regimes designed to prevent the mobilities that have defined these waters from earliest antiquity. This article considers initial results of fieldwork undertaken to document and make visible the material culture of contemporary vessels used to carry forced and undocumented migrants to southeast Sicily over the past decade. These former fishing craft reveal structural and spatial adaptations to facilitate a different traffic, reflected also in items left behind when the boats were intercepted. Archaeology helps to embed these journeys within long-term frameworks of connectivity and to situate their ephemeral traces alongside more traditional notions of Mediterranean maritime heritage. In a region that celebrates its deep connections to the sea, care for the materiality of these contemporary mobilities foregrounds human experiences, while serving goals of advocacy, empowerment, and social justice amid global change. ${ }^{1}$

\section{INTRODUCTION}

Since 2013, the Marzamemi Maritime Heritage Project (MMHP) has undertaken collaborative excavation, survey, and heritage management initiatives focusing on the maritime landscape and seaborne communication along southeast Sicily, Italy. ${ }^{2}$ Through survey and excavation of the sixth-century CE shipwreck at Marzamemi (2013-19), the project considered the Late Antique transformation of economic, political, social, and religious links visible at this intersection of the Mediterranean. Scientific studies of ships and shipwrecks have for six decades provided a path toward exploration of the

\footnotetext{
${ }^{1}$ We are grateful to many individuals and institutions who encouraged us to pursue a project outside traditional disciplinary boundaries, especially Richard Leventhal and Brian Daniels of the Penn Cultural Heritage Center. Support has been provided, within the framework of the Marzamemi Maritime Heritage Project (MMHP) more generally (see Leidwanger et al. 2021a, n. 1), by Brock University, Stanford University, and Suor Orsola Benincasa University of Naples, as well as the Canada Foundation for Innovation, Ontario Research Fund, and Social Sciences and Humanities Research Council of Canada. For permission to record the boats in 2019 and discussion about their arrival in Pozzallo we thank Major Salvatore Caltagirone and Giuseppe Savasta. Logistical assistance from Matteo Azarro, Nicola Scotto di Carlo, and Rachel Stark benefited the work, as did work by students Fahdah Al Subayhin, Kelly Dunn, Paul Gorka, Liz Hoffer, Omar Khoury, Olivia Tucker, and Sophia Zamoyski. The AJA Editors-in-ChiefEmma Blake and Rob Schon and anonymous reviewers provided invaluable feedback, as did audiences at the Archaeological Institute of America, Bishop's University, Stanford University, University of Pennsylvania, University of Toronto, and Western University. Images courtesy MMHP or the authors unless otherwise noted.

${ }^{2}$ See Leidwanger et al. 2021a; 2021 b.
} 
goods, people, and processes that linked the ancient Mediterranean, with increasing attention dedicated to the multiple layers of interaction that balance elite and state-driven narratives with the everyday activities that occurred on a scale less visible in the archaeological record. ${ }^{3}$ They also contribute to a broader dialogue on responsible collaborative heritage practices that consider the long-term and multifaceted relationship between the sea, the coast, and the peoples connected along and across these waters. Braudel famously asserted that the Mediterranean's defining feature was incessant mobility, ${ }^{4}$ and the extension, back into deep prehistory and up to modernity, of Horden and Purcell's "corrupting sea" that connected microecologies and communities, lays bare the incontrovertible links between the past and present of maritime interaction. ${ }^{5}$ But even as similar meshworks of connectivity utilized in antiquity to manage environmental, economic, military, and other risks might be visible in the boats, routes, and weather patterns of the contemporary sea, so too are the barriers to mobility that continue to create a carceral maritime landscape, restricting many border crossers to a permanently liminal space. ${ }^{6} \mathrm{Ar}-$ chaeologists can no longer excavate ancient mobilities and past interactions without also considering how the globalized world that emerged from these trajectories and their historical reception has in turn transformed the nature of contemporary Mediterranean connections. As heritage professionals, we see advocacy for social justice and positive change as fundamental to a 21 st-century archaeology that sets as part of its mission the engaging of diverse communities with the meaning of the past in the present. ${ }^{7}$

\footnotetext{
${ }^{3}$ Leidwanger 2020.

${ }^{4}$ Braudel 1972, 276: "The Mediterranean has no unity but that created by the movements of men, the relations they imply, and the routes they follow."

${ }^{5}$ Horden and Purcell 2000; for this model further back in prehistory or forward into early modernity, see also, respectively, Broodbank 2013; Tabak 2008.

${ }^{6}$ Dickson 2021a suggests with respect to migration law that the seas "have become incorporated into an architecture of carcerality, facilitating the interruption of autonomous mobility as well as practices of disciplined mobility."

${ }^{7}$ See Janes and Sandell 2019; also Vlachou 2019, 55, in the same volume, who explains the imperative for museums to address issues of migration, noting in the present climate that "moments of crisis, such as this, require us to listen better and to do some self-reflection too. It becomes increasingly impor-
}

The title of this article reflects our active choice to record - as challenging archaeological heritage-a series of modern boats, impounded in southeast Sicilian ports, that brought recent migrants across the central Mediterranean from North Africa to Europe. The boats and the abandoned objects they contain, marking one brief leg of much longer and often ongoing journeys, might be considered within the category of ephemera, the "minor transient documents of everyday life;" here they stand as impermanent markers of transition. Our decision to record these objects-viewed from a bureaucratic perspective alternately as coastal pollution or material witness to illicit activity-using approaches developed for the recording of ancient ships inscribes them within longer-term mobilities and situates them alongside more traditional notions of Mediterranean heritage. In a corner of Sicily that identifies through deep connections to and across the sea, care for the material markers of these movements foregrounds the human experience, while serving goals of advocacy, empowerment, and social justice amid global change. To such an end, this is an activist contribution in that we consider contemporary movements across the central Mediterranean as embedded within longer historic phenomena of Eurocentric and imperialist narratives that have long defined classical archaeology and its reception, particularly with respect to Italian colonialism in Libya and East Africa. Today's border regimes reflect the legacy of ancient pasts, their historical reception, and the current moment of the planet at a critical juncture, produced by unsustainable resource exploitation, climate change, economic inequality, growing populations, systemic racism, and anti-immigrant sentiments. ${ }^{9}$ This archaeology engages

tant for museums to be clear about who they are- to state what they stand for (through explicit expressions of mission and values) - and, importantly, to work in accordance with these statements." Archaeology faces a similar imperative.

${ }^{8}$ Rickards 1988,7 , to borrow a term more commonly applied to short-lived printed or written matter, such as advertisements, almanacs, trading cards, or letters.

${ }^{9}$ Smythe's (2018, 7-8) Black Mediterranean "represents a demand to acknowledge the connection between the present and the past-including the history of colonialism, emigration and intranational migration-in which Italians have occupied positions of both hegemony and subalternity in different historical times and geographical locations." See also Di Maio 2013, 42-43; Proglio 2018, 409-14. For detailed bibliography and approaches to the materiality and heritage of forced migration, 
with what Sharpe calls "wake work," evoking not only consciousness but also the wake of the ship as it traverses the sea, and mindful remembrance of those who made and continue to attempt these journeys. Such work might be seen as "grounded in the knowledge of the wake, in a past that is not past, a past that is with us still; a past that cannot and should not be pacified in its presentation." ${ }^{10}$ The inclusion of contemporary heritage within the broader discipline of Mediterranean archaeology compels us to consider our role in the production of partial histories of mobility that celebrate the sea's past and present bridges while overlooking some of its more consequential barriers.

\section{BACKGROUND AND LEGAL REGIMES}

The central Mediterranean today marks one of the most active and dangerous routes for migrant sea crossings to Europe, due in no small part to border regimes designed to prevent the very mobilities that have defined these waters from earliest antiquity (fig. 1). ${ }^{11}$ Any such discussion of policy requires an explanation of terminology. For many, mobility across the Mediterranean and the possibility of refuge in Europe are predicated today on achieving refugee status, as defined in the United Nations 1951 Convention Relating to the Status of Refugees and its 1967 Protocol, ${ }^{12}$ the 1969 Organisation of African Unity (OAU) Convention Governing the Specific Aspects of Refugee Problems in Africa, ${ }^{13}$ and the 1984 Cartagena Declaration on

including traditions of activist and contemporary archaeologies, see McGuire 2020.

${ }^{10}$ Sharpe 2016, 1-22, quote on 62.

${ }^{11}$ The International Organization for Migration (IOM) Missing Migrants Project tracks the number of people who have died or gone missing along migration routes worldwide. Mediterranean data can be found at https://missingmigrants.iom. int/region/mediterranean.

${ }^{12}$ Article 1A(2) of the 1951 Convention (www.unhcr.org/ $5 \mathrm{~d} 9 \mathrm{ed} 32 \mathrm{~b} 4)$ defines a refugee as any person who, "owing to well-founded fear of being persecuted for reasons of race, religion, nationality, membership of a particular social group or political opinion, is outside the country of his nationality and is unable or, owing to such fear, is unwilling to avail himself of the protection of that country; or who, not having a nationality and being outside the country of his former habitual residence as a result of such events, is unable or, owing to such fear, is unwilling to return to it."

${ }^{13}$ Article 1.2 of the 1969 OAU Convention Governing the Specific Aspects of Refugee Problems in Africa (www.unhcr. org/about-us/background/45dcla682) expands this defini-

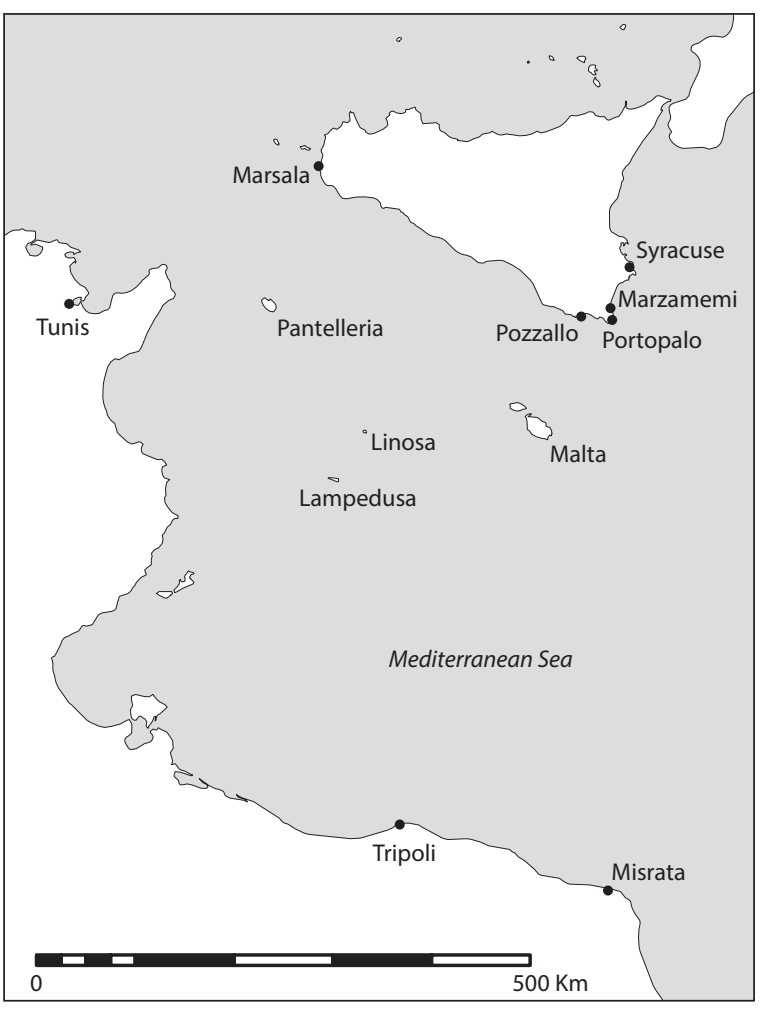

FIG. 1. Map of the central Mediterranean indicating locations discussed in the text.

Refugees. ${ }^{14}$ Legal refugee status is distinct from that of other displaced persons, frequently deemed "undocumented" or "economic" migrants, and considered separately in terms of law and human rights. In this study we use "migrant" as an inclusive, rather than exclusive, term for all who cross borders, evoking the process of

tion to note, "The term 'refugee' shall also apply to every person who, owing to external aggression, occupation, foreign domination or events seriously disturbing public order in either part or the whole of his country of origin or nationality, is compelled to leave his place of habitual residence in order to seek refuge in another place outside his country of origin or nationality."

${ }^{14}$ Conclusion 3.3 of the 1984 Cartagena Declaration on Refugees, from the Colloquium on the International Protection of Refugees in Central America, Mexico and Panama (www. unhcr.org/about-us/background/45dc19084/), expands further to include among refugees "persons who have fled their country because their lives, safety or freedom have been threatened by generalized violence, foreign aggression, internal conflicts, massive violation of human rights or other circumstances which have seriously disturbed public order." 
movement rather than a status of personhood, and advocating for a more inclusive framework of mobility. ${ }^{15}$

In the central Mediterranean, border regimes operate according to national Italian and EU-based frameworks, juggling competing narratives of humanitarianism, or the need to save lives and protect human rights, and securitization, or the combatting of illegal immigration, human trafficking, and terrorist threats. ${ }^{16}$ Implementation of these strategies in a maritime context has been effected through targeted initiatives in states facing high migratory pressures, such as Italy, Greece, and Spain, and through collaborations with African nations and Turkey to develop and enforce extraterritorial strategies that move control mechanisms away from European borders. In 2013, following popular awareness of two shipwrecks off Lampedusa that claimed more than 600 lives, Italy implemented the military-humanitarian operation Mare Nostrum, aimed at rescuing migrants, arresting smugglers, and stopping the entry of unauthorized migrants. ${ }^{17}$ The humanitarian search and rescue aspects of Mare Nostrum were largely superseded by security interests, with its replacement in 2015 by Operation Mare Sicuro, as well as the Frontex-led Triton (replaced by Themis in 2018) and EU Naval Force (EUNAVFOR) Mediterranean Operation Sophia (replaced by Irini in 2020). At the same time, EU Border Assistance Mission (EUBAM) Libya and EU Capacity Building Mission (EUCAP) Mali and Niger aim at external capacity building to help disrupt criminal networks of human trafficking and terrorism, and to deter movement at its source. In the Mediterranean, restrictions, criminal and administrative proceedings, and other limitations on search and rescue operations by nongovernmental organizations have made the crossing additionally perilous as the movements of displaced people are

\footnotetext{
${ }^{15}$ On the topic of terminology used to describe displaced persons who cross borders, and distinctions between migrants and refugees, see discussion by Hamilakis $(2018,2-3)$ and Kiddey (2019, 600, 619 n. 1). The office of the United Nations High Commissioner for Refugees (UNHCR) describes "refugees and migrants" in recognition of the legal distinction (see Edwards 2016). Our choice of terminology reflects an archaeological approach to contesting the rigid dichotomy between processes of movement with multiple underlying causes (Crawley and Skleparis 2018, 52).

${ }^{16}$ Terlizzi 2019, 25-28; see Perkowski 2016, 332-33, for blurred boundaries between these discourses.

${ }^{17}$ Tazzioli 2016.
}

entangled among trafficking networks of cigarettes, narcotics, petroleum, and arms. ${ }^{18}$

The Mediterranean operations led by Italy and the European Union are notable for naming conventions that evoke ancient history and classical mythology. Personifications of wisdom (Sophia), peace (Eirene), and divine justice (Themis) tie control of the sea to universalizing principles of order. Triton recalls the mythic son of Poseidon and Amphitrite and, paradoxically, the Libyan lake god who pledged to the Argonauts future Greek settlement in Cyrene. Mare Nostrum evokes Roman imperial hegemony over the Mediterranean, predicated on the defeat of Carthage in the Punic wars. Agbamu has drawn parallels between the literary imagination of ancient Rome, its revival in the 19th and 20th centuries to legitimize Italian sovereignty across the Mediterranean, and the recent self-representation of Italy as guardian of the walls of Fortress Europe. ${ }^{19}$ On the other hand, responding in 2018 to the closure of Italian ports to the rescue ship Aquarius with 629 people on board, Palermo mayor Leoluca Orlando described his city as a place of refuge, invoking its ancient name Panormus as a "complete port" that should offer safety to all. ${ }^{20}$ These parallel trajectories reflect what Agbamu recognizes as Italy's protean relationship with the sea, with policies that shift "from claiming mare nostrum to rejecting it." 1 Through such critical frameworks, the Mediterranean becomes both bridge and barrier, calling forth ancient paradigms of connectivity and control. The COVID19 pandemic has presented additional challenges to mobility as border restrictions and quarantines are intensified in the name of public safety, resulting in port closures, delays in disembarkation, and the reduced presence of search and rescue missions. ${ }^{22}$

\footnotetext{
${ }^{18}$ Malakooti and Fall 2020, 102; see also analysis of the intersection of external regimes with long-term local and regional mobility structures across the Sahara in Scheele 2012.

${ }^{19}$ Agbamu 2019, 254; Smythe (2018, 7-8) highlights the "demand to acknowledge the connection between the present and the past-including the history of colonialism, emigration and intranational migration."

${ }^{20}$ Wintour et al. 2018. Ancient geographers more likely intended "Panormus" to signify a port that was safe in all winds and seasons.

${ }^{21}$ Agbamu 2019, 273; Tazzioli (2016, 6-7) describes the protean borders of migration governmentality.

${ }^{22}$ Carney 2020; IMREF 2020.
} 


\section{ARCHAEOLOGY AND MIGRANT CROSSINGS}

The power of archaeology to raise awareness of policy decisions and their human impacts has been demonstrated by De León in his work on migrant crossings through the Sonoran Desert of Arizona from Mexico to the United States. ${ }^{23}$ In academic writing and exhibitions for the public, De León explores the deadly effect of the federal border patrol policy known as "Prevention Through Deterrence," which closed borders to immigration at major urban centers, pushing migrants onto far more dangerous paths through extreme landscapes. Mediterranean crossings often utilize the same general paths as followed since the earliest of times, and the sea route between Sicily's southeastern tip (ancient Cape Pachynus) and the opposite Libyan shore was well known in antiquity. ${ }^{24}$ The actions and strategies that allow passage across these waters, however, have been adapted in response to changing policies. The shift from humanitarian search and rescue to externalization and securitization strategies in regimes of border control creates greater threats to the initial stages of maritime journeys, in which boats must covertly exit territorial waters to avoid interception and return. Forsaking major ports and their associated knowledge networks of local expertise, migrants now depart from covert beaches in the dark of night with a basic compass heading and an Internet weather forecast. Unprepared mariners are sent off by traffickers on schedules that might ignore local winds, weather, and seasonal hazards; transgressions from traditional routes and schedules may result in greater cover for vessels attempting to exit national borders without intervention. ${ }^{25}$ Moreover, the journeys are undertaken in retired and repurposed fishing boats or flimsy inflatables, unaccustomed and unequipped for such work. Today, large vessels that steer direct paths into Italian waters with a goal of humanitarian interception comprise a decreasing percentage of arrivals in comparison to smaller boats aimed at isolated drop points on shore; these sbarchifantasma (or ghost landings) allow

\footnotetext{
${ }^{23}$ De León 2015; Gokee et al. 2020. Also see the comprehensive discussion on the archaeologies of forced and undocumented migration in Hamilakis 2018.

${ }^{24}$ Ptol., Geog. 1.15.2: "Pachynus [Pachino] is opposite Leptis Magna”; see also, generally, Arnaud 2005, 182-83.

${ }^{25}$ Friese 2015 and Ben-Yehoyada 2011 stress the importance of local knowledge networks in understanding the topography of the central Mediterranean.
}

migrants to vanish upon reaching shore. ${ }^{26}$ Clandestine arrivals of small boats at makeshift landings are known even from antiquity and have come to be seen as the most viable paths, despite their obvious dangers. ${ }^{27}$ These changing mobilities leave traces in the material record, revealing the shifting human experiences on a sea that has been constructed as perilous through politics rather than historical geography. ${ }^{28}$

Over the course of our work on the Late Antique shipwreck at Marzamemi, located just under $500 \mathrm{~km}$ north of Misrata, Libya, an evolving series of vessels from such voyages were abandoned and impounded in local ports. ${ }^{29}$ These brightly colored fishing boats mark official interceptions and unrecorded landings of migrants to Italy. Between 2013 and 2019, we observed a changing array of boats along these Sicilian shores, as they were moved year to year from shore to port to impoundment area, subject variously to burning, destruction, and occasional forms of ad hoc curation, but ultimately also replacement by new arrivals (fig. 2). What began as part of the MMHP's goals to consider an ancient shipwreck in the context of the local maritime landscape and historic livelihoods on and around the sea led us to examine more closely these material markers of recent seaborne connections and their understanding within the community as artifacts of memory. Initial efforts focused on basic photographic recording of vessels in Marzamemi, Portopalo di Capo Passero, and Pozzallo (see fig. 1).

We were by no means the first to document this ephemeral heritage; online photographs of these vessels display peeling paint, evocative graffiti, and various states of preservation-from intact hulls to burnt timbers. The Flickr page of photographer and activist Paul Keller records now long vanished migrant boats tied to the breakwater at Marzamemi as early as $2009 .{ }^{30}$ Abandoned vessels on the shores of nearby

\footnotetext{
${ }^{26}$ Indelicato 2020. Blake and Schon 2019 provide archaeological evidence for such contemporary phenomena.

${ }^{27}$ See Leidwanger 2013 and Leonard 2021 on alternate networks of interaction that relied on makeshift ports rather than official entry points.

${ }^{28}$ Dickson (2021b, 999-1002) describes the conscious political configuration of the central Mediterranean as a perilous, fatal, and ungovernable space for migrants.

${ }^{29}$ Misrata is surrounded by migrant detention centers at Karareem (closed in 2019), Zliten, and Souq Al Khamees.

${ }^{30}$ E.g., Paul Keller, www.flickr.com/photos/paulk/4063897 248/in/photostream/.
} 


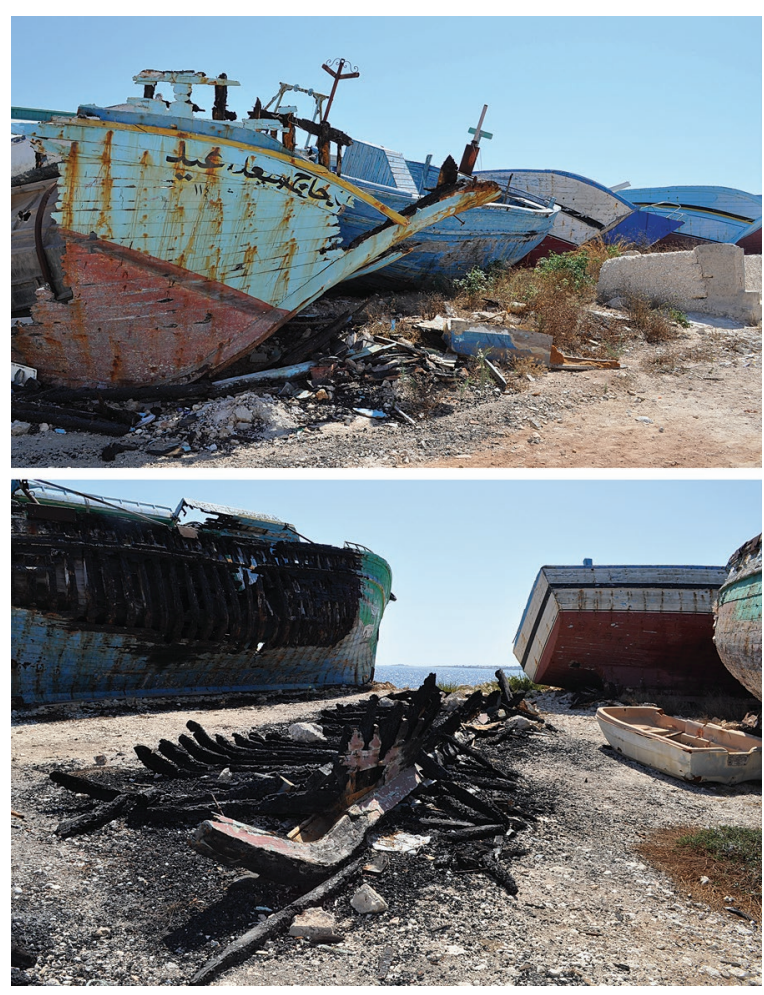

FIG. 2. Migrant boats in the harbor of Portopalo in various stages of deterioration and destruction, photographed in 2017.

Portopalo are common photographic subjects, showcased by artists and travel bloggers alike as a means of generating concern and support, but also inviting what Hamilakis has described as a "twenty-first-century ruin lust," drawing on public fascination with tragedy. ${ }^{31}$ As a means of reflexive engagement with the connections of these boats to the Late Antique shipwreck we were excavating underwater at Marzamemi, in 2016 we began documenting these vessels. By 2019, the area had been largely cleared; some of the recognizable boats had been transferred unceremoniously to a fenced impoundment lot, while others were burned in place or removed for destruction. The painted names and registration numbers of these early arrivals evoke

\footnotetext{
${ }^{31}$ See, e.g., Davide Germano's photographic montage, "The Migrants Boats of Portopalo": www.davidegermanopho tography.com/border_galleries/the-migrants-boats-of-porto palo/\#; also the photographic journal of János Chialá: www. postphotography.eu/2013/11/22/the-boats-on-the-shore/; and the Wordpress travel blog of Stana Ferrari: https:// travelwithstanito.wordpress.com/2014/08/08/sicilys-ref ugees-boats-graveyard. Hamilakis $(2018,14)$ warns of shipwrecked boats as the subjects of a photographic "refugee porn."
}

their prior lives as fishing vessels, with names such as Salma bi ithn Allah (Salma is with Allah) expressing sentiments of hope and faith equally valid for fishermen and migrants alike. Some display more recently added imagery of cars, clocktowers, and sketched faces. Holes punctured through bow timbers allowed some to be towed; propellers have been salvaged or transformed into marine souvenirs. Even after years of neglect, shoes and clothing, wrappers and containers, and other markers of the passage remain visible within the hulls. From Pozzallo, we were given working snapshots taken between 2014 and 2015 by Giuseppe Savasta, of the Pozzallo-based harbor services and warehousing company Savasta Service, which was contracted to remove intercepted boats from the water and place them on shore. These photographs serve as a lone record of the continual process as new boats arrive to replace those destroyed.

\section{HERITAGE FROM BELOW AND AN}

\section{ARCHAEOLOGY OF CARE}

Aware of this cycle of deposition and destruction, in July 2019 we undertook as rescue work the recording of four wooden boats impounded in the harbor of Pozzallo and slated for imminent destruction by judicial order as unregistered and unseaworthy vessels seized in anti-trafficking operations. Access to the boats required permission from the local Guardia di Finanza (Finance Police), the authority more broadly responsible on land and sea for handling financial crimes like smuggling and trafficking, and frequently therefore charged with intervention, detainment, and processing of migrant vessels that enter Italian waters. ${ }^{32}$ Members of several of the Guardia's local offices, including at Pozzallo, had previously collaborated in archaeological research on the Late Antique Marzamemi shipwreck by helping raise marble architectural elements of the cargo from the seabed at the end of excavation seasons.

As archaeologists and heritage professionals, we are tied into traditional permitting structures. Our

\footnotetext{
${ }^{32}$ Permission to record the boats in 2019 was granted by Major Salvatore Caltagirone (Reparto Operativo Aeronavale della Guardia di Finanza di Palermo; Sezione Operativa Navale della Guardia di Finanza di Pozzallo). According to Caltagirone, intercepted boats that can continue sailing are brought to port; those unable to continue navigation for reasons of safety are disembarked, then may be left adrift upon issuance of an AVURNAV (urgent notice to mariners) to report the presence of a damaged and adrift vessel.
} 
research on ancient shipwrecks has been undertaken as a collaboration with the Sicilian Soprintendenza del Mare. The migrant boats, however, do not fall under the purview of any archaeological office; instead, their fate is determined by the Procura della Repubblica (Public Prosecutor) and the Agenzia delle Dogane e dei Monopoli (Customs and Monopolies Agency), with its mandate over goods entering the EU and criminal activity such as smuggling, counterfeiting, money laundering, and illicit trafficking. Our practical handling of the vessels as sites and assemblages of archaeological study, and in the process their unofficial inscription as heritage, contrasts with formal designations by national and international authorities. ${ }^{33} \mathrm{In}$ recording these objects as archaeological assemblages, our work seeks to "engage 'heritage' on a more personal register, cognitively and emotionally, regardless of mandates of official top-down heritage(scapes)." ${ }^{34}$ As an alternative to official heritage regimes, the creation of such "heritage from below" reflects a goal of making visible counter-narratives and counter-sites of memory that stand alongside more traditional images and unfinished histories of Sicily's maritime past. ${ }^{35}$

We cannot fail to recognize that our positionality as white, North American and Italian academics with university affiliations and multiyear connections to the region allowed us particular access to these boats from which others are excluded. ${ }^{36}$ There is an inherent ethical contradiction in being granted permission to work on this material by the same institutions implicated in the surveillance of borders, the interception of migrants, and the destruction of

\footnotetext{
${ }^{33} \mathrm{On}$ the challenges and limitations of such heritage bureaucracy, see Meskell 2002; 2018.

${ }^{34}$ Muzaini and Minca 2018, 2, building on Robertson 2012. See Kiddey 2018, 701-5, on heritage practices as tools for empowerment; De León and Gokee 2018, 84, for the suggestion that "rather than just telling different stories about the immediate past and present, archaeology of the contemporary can also help us better understand the privilege and power that underlies notions of heritage."

${ }^{35}$ González-Ruibal (2019, 99-102) discusses archaeology as participating in an obligation to make visible the collective memory of marginalized communities. On the idea of "unfinished geographies" as counter-narratives, see Cook and Potter 2018.

${ }^{36}$ Queirolo Palmas $(2020,858)$ describes the experience of returning to Pozzallo with an asylum seeker to Italy, who had arrived there three years earlier; both were denied access to the controlled area.
}

boats. De León has noted, "As memories of border crossings fade with time, physical evidence is being systematically removed by the political system that created this phenomenon. ${ }^{37}$ And yet, despite the unusual nature of our request to document these vessels, we faced no significant bureaucratic roadblocks in these activities. Over the course of multiple conversations with officials and workers in the port area, the tension was palpable between the enactment of formal duties of intervention and an awareness of a broader humanitarian responsibility. Since undertaking our salvage recording, we have been working to develop initiatives that engage migrant communities and other local stakeholders in the creation of material-based narratives of mobility, cognizant that the objectives of archaeological recording and their connection to heritage work might stand at odds with official documentation protocols that create systemic exclusion. Together we aim to build insight into how archaeologists and communities can together chronicle the experiences of displacement and migration without risking retraumatization, or seeming to solicit narratives of suffering or "deservingness." 38 The global COVID-19 pandemic has forced us to put these plans on hold temporarily, even as it highlights the ongoing relevance of such work. We are aware that, as a result, the current discussion reflects only a partial story. ${ }^{39}$

As a conceptual framework for viewing this challenging heritage together with ancient maritime movement, our work is indebted to multiple scholars who remind us to foreground empathy, trust, solidarity, and mutual concern in defining archaeological research. Following Held and Tronto's conceptualization of an "ethics of care" as a guiding moral imperative that prioritizes relationships and social bonds on individual, community, and global-political levels, ${ }^{40}$ Bounia considers heritage approaches to contemporary migration and other social crises. She notes that "to care' means to recognize histories of injustice, not only via empathy, but also by taking responsibility for injustice, as well as for the system that produces it and allows

\footnotetext{
${ }^{37}$ De León 2015, 201.

${ }^{38}$ Carney 2021, 84-85.

${ }^{39}$ González-Ruibal $(2019,97)$ notes the power of archaeology to "embody the experience of the contemporary era, its pain and its drama" through "a heterogeneous mixture of things, times and fragmentary tales."

${ }^{40} \mathrm{Held} 2006$; Tronto 2010. On heritage and an ethics of care, see Kiddey 2017, 52-68.
} 
people to be treated differently." ${ }^{41}$ Kiddey has applied such an ethic of care to archaeological work in Britain and Greece, documenting urban heritage and makeshift shelters together with homeless communities that are normally excluded from the process of archaeological knowledge-making. For Kiddey, "ethically sound cultural heritage work is ... conscious of itself as a powerful and potentially democratizing influence in the world." ${ }^{42}$ Caraher, Weber, and Rothaus describe "an 'archaeology of care' which regards the archaeological process as an expression of concern from the archaeological community" in recognition of human consequences of disciplinary methods and created pasts; while Supernant, Baxter, Lyons, and Atalay describe self-reflexive, "archaeologies of the heart" built from rigor, care, relationality, and emotion in a world "that grows from our strengths and doesn't take for granted oppressive, unjust, and exploitative practices." ${ }^{\prime 3}$ It is within these traditions that we have attempted to situate our own work.

\section{POZZALLO BOAT \#179}

In late June and early July 2019, a small archaeological team from the MMHP undertook documentation of a variety of vessels and their associated material assemblages in the restricted customs area in the commercial port at Pozzallo. In addition to various deflated RHIBs (rigid-hull inflatable boats) and small fiberglass shells, four were slightly larger wooden hulls of repurposed fishing vessels, ranging in length from about 7 to $15 \mathrm{~m}$ (fig. 3). Boats intercepted by Italian authorities are brought to designated "hotspots" (formerly known as "First Aid and Reception Centers"), where migrants are identified, registered, fingerprinted, and provided with preliminary medical care, then accompanied to a nearby reception center; meanwhile, the vessel is seized and subject to inspection and reconnaissance for information and equipment relevant to the trafficking investigation.

The primary archaeological focus of the present article centers on the vessel labeled "179," the most recent of the four and the one that retained the most complex material assemblage. This designation reflects the number assigned upon its impoundment by the au-

\footnotetext{
${ }^{41}$ Bounia 2020, 42.

${ }^{42}$ Kiddey 2017, 54.

${ }^{43}$ Caraher et al. 2018, 95; Caraher 2019, 381; Atalay 2020, 256, and other contributions in Supernant et al. 2020.
}

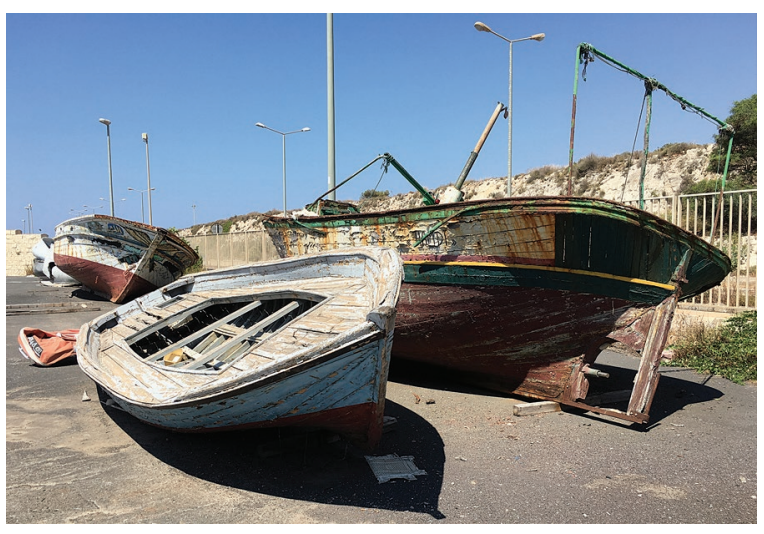

FIG. 3. Impounded boats in the Pozzallo harbor, recorded archaeologically by the authors in late June and early July 2019.

thorities of Pozzallo, spray-painted in dull red on both sides of the bow and the transom, now missing its propeller (fig. 4). Its original name and registration number have been obscured with a tangle of black spray paint, leaving visible only a few bright red stars on the bow and stempost, but its arrival to Italy was reported by the United Nations' International Organization for Migration (IOM): ${ }^{44}$

IOM Rome's Flavio Di Giacomo on Monday reported that on Saturday evening (24 November [2018]), a boat carrying 264 migrants arrived at Pozzallo, Sicily. The migrants remained on board for about three hours before disembarking at the port, where IOM staff provided assistance. Most of these migrants came from the Horn of Africa. Migrants on board told IOM staff [that] they had left Libya from the port of Misrata on the night of 22-23 November. Their wooden fishing boat was divided into three decks.

These migrants reported they had been stranded in Libya between one and two years. Many insisted they had been kidnapped and then tortured for ransom and sold several times between groups of traffickers.

"Landings with more than 200 people on board have become a rare phenomenon," said Di Giacomo, "and it is extremely unusual that such an unseaworthy boat manages to reach the Italian coasts. These are boats completely unsuited for such travel and could sink at any moment. The rescue operations at the port were in fact particularly complicated because the boat was completely unstable."

A truncated report, including two photographsone of migrants wrapped in gold rescue blankets, the other of still-wet personal items left behind on deck-

\footnotetext{
${ }^{44}$ IOM 2018.
} 

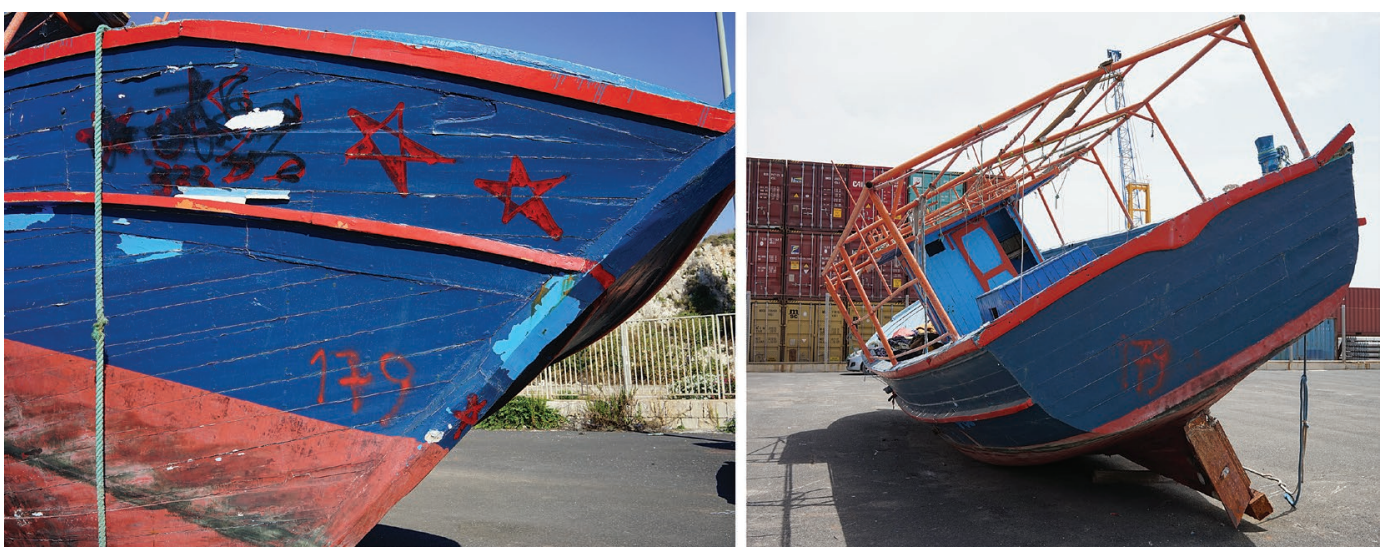

FIG. 4. Spray-painted to the bow and transom by Italian authorities following interception, the number " 179 " is now the only name borne by the former fishing boat.

appeared on the Twitter feed of the office of the United Nations High Commissioner for Refugees (UNHCR) in Italy, which described " 264 persone partite da Misrata \#Libia il 22/11. 40 donne, 44 minori (33 soli). 233 eritrei, per 1-2 anni nelle prigioni dei trafficanti. Sopravvissuti a torture, abusi, malnutrizione; riscatto pagato più volte. Una bimba di 15 gg nata in hangar senza assistenza medica" (264 people left Misrata \#Libya on 11/22. 40 women, 44 minors (33 unaccompanied). 233 Eritreans, for 1-2 years in traffickers' prisons. Survivors of torture, abuse, malnutrition; ransom paid multiple times. A 15-day-old girl born in a hangar without medical assistance).$^{45}$ Subsequent news reports of the boat are limited to the humaninterest story of the mother and her 15-day old infant, as aid agencies and the media moved on to newer arrivals. We understand that the migrants were brought to local detention centers according to policy, though we were not provided specific information about their current location or status.

Our focus on material culture - the boats themselves and the items left behind-reflects an attempt to tell the story of contemporary migration in a different way, moving beyond statistical records or poignant journalistic story lines, and challenging the erasure of events and artifacts through archaeological recording. ${ }^{46}$ To this end, we consider polyvocal archaeological data rather than individualized stories of human experi-

\footnotetext{
${ }^{45}$ https://twitter.com/UNHCRItalia/status/10666355796 71146496.

${ }^{46}$ González-Ruibal 2008, 248-52; 2019, 116-20, on archaeology as a form of redress to attempts at erasure.
}

ence. ${ }^{47}$ As archaeologists, we are accustomed to close observation of objects, assemblages, and contexts; moreover, the archaeological lens offers a view of a broader picture, including adaptations, preparations, and other information to which migrants would not have access. ${ }^{48}$ We approach archaeology as a blend of humanistic and social science discourse, with an aim of recording diachronic histories through object assemblages. Our photographs offer documentation of boats that arrived at Sicilian ports; we do not practice forensic analysis or recovery of the shipwrecks that memorialize the tragedy of failed crossings and make up more than one in 20 attempts. ${ }^{49}$ As the initiative of maritime archaeologists with academic interests spanning millennia, this approach reflects our commitment to recording the material culture of journeys across the central Mediterranean as an ongoing phenomenon embedded in longer-term and geographically broader contexts.

Our recording of this boat incorporated traditional archaeological methods, including photography and 3D documentation with a Faro Focus S70 laser scanner to generate a model of the vessel's structure, surfaces,

\footnotetext{
${ }^{47}$ De León 2015,172 . For ethnographic approaches to Mediterranean crossings, see the narratives related by Lucht 2012, Alexander-Nathani 2021, and Pamela Kerpuis' Migrants of the Mediterranean humanitarian storytelling project (www.mig rantsofthemed.com). These and many other projects productively navigate what Andersson (2014) and Cabot $(2019,269)$ warn as "anthropology's complicity in the refugee regime."

${ }^{48}$ See, e.g., Tzafalias 2016 on life jackets filled with compressed paper or bubble wrap.

${ }^{49}$ Olivieri et al. 2018; M'charek and Casartelli 2019.
} 
and contents with high-resolution detail for archiving and analysis. Such techniques are typical for the digital archiving of world heritage and are increasingly used for the recording and reconstruction of boats of archaeological or historic interest. ${ }^{50}$ Following this preliminary record, individual objects and features were documented according to designated sectors within the vessel. Through a comprehensive system that did not privilege the recording of any particular objects over any others, we attempted to minimize the risk of aestheticization or romanticization of the assemblage. ${ }^{51}$ Documentation took place over the course of a two-week period in late June and early July 2019; the rapid schedule was determined by destruction orders issued by a local magistrate for the vessels, and although they had not been implemented by the time we departed Sicily later that summer, as of fall 2021 the area has been completely cleared. The boat's structure and artifacts were primarily recorded on-site, but smaller scraps of fragile paper that could not be detailed sufficiently in the field were transported to our research facility in Marzamemi for further documentation before being returned. Safety protocols kept us from thorough recording in all areas of the ship; we relied only on photographic documentation in certain areas where we encountered standing (diesel) fuel spill or visible biological materials, including areas below deck forward and aft, and the toilet. No photographs of objects or information that could be directly tied to specific individuals have been included in this article.

\section{The Vessel's Hull and Spaces}

The wooden boat measures $12.67 \times 4.27 \mathrm{~m}$, with three levels of varying dimensions (fig. 5): the hold (sectors 10,11), the main deck with wheelhouse (sectors 1-8), and a plywood-covered area above the wheelhouse extended on the starboard side by rough planking and accessible by a ladder attached to the port rail (sector 9). Behind the wheelhouse (sector 6) was a washroom containing a single toilet on the port side (sector 8), and an enclosed area with shelves on

\footnotetext{
${ }^{50}$ See, e.g., Repola et al. 2017; 2020 on the recording of historic boats and structures associated with the tuna-fishing industry in Portopalo. The techniques described were used for all four boats recorded in the Pozzallo port.

${ }^{51}$ See Hamilakis 2018, 12-16, and González-Ruibal 2008, 251 , for warnings against such choices in the recording and display of difficult heritage and thoughts on reflexive practice.
}

the starboard side (sector 7 ). Space below deck was divided into a bow region (sector 10), a covered central area containing a large diesel engine, and a stern area (sector 11 forward and aft). The bow and stern regions were accessible through small rectangular hatches in the deck; the stern hold was fitted to be locked, originally for the protection of boat equipment and crew members' possessions. It was unclear whether locking mechanisms were in place during the vessel's last voyage. Each of the two compartments below deck contained several low bunks for the vessel's previous crew. A larger opening just aft of center provided access to the engine.

Certain structural modifications suggested the boat's swift conversion from a fishing vessel to one for trafficking people (fig. 6). ${ }^{52}$ Occasional hooks and rope fragments hinted at the vessel's original purpose, but all major fishing equipment had been removed. Evidence of the quick shift can be seen in the retention of fitted cushions in the wheelhouse (sector 6), and thin mattresses on built shelf-like bunks in the stern hold (sector $11 \mathrm{aft}$ ). The wheelhouse cabinets and engine area retained rusted tools, partial containers of fuel, oil, grease, expired caulking, and other supply and repair items used over a long period of the ship's life; a tube of waterproofing hardener produced in April 2018 may reflect repairs made shortly before the vessel's repurposing. On the other hand, a plastic scraper and blobs of putty stuck to a juice box on the wheelhouse console may suggest repairs undertaken just before or over the course of the final journey. The red metal framework above the central and stern area (sectors 3-5) must once have supported a removable tarpaulin shade for those undertaking work on deck. Here, we recorded multiple looped bits of assorted rope and twine descending from the bars. These likely supported a network of makeshift shades as well as handgrips for the multiple people standing or maneuvering on a crowded deck. Black rubber hoses newly punched through the hull vented diesel fumes and toilet debris off the port side. The spaces between frame extensions above deck seem to have been repurposed as storage cubbies for individual or small group possessions, often collected together in plastic bags. Scupper holes on both sides of the hull were generally found blocked.

\footnotetext{
${ }^{52}$ De León et al. 2015, 159-63, discuss the idea of migrantspecific modification, use, and reuse of objects whose traces can open up new understandings of border crossing activities.
} 

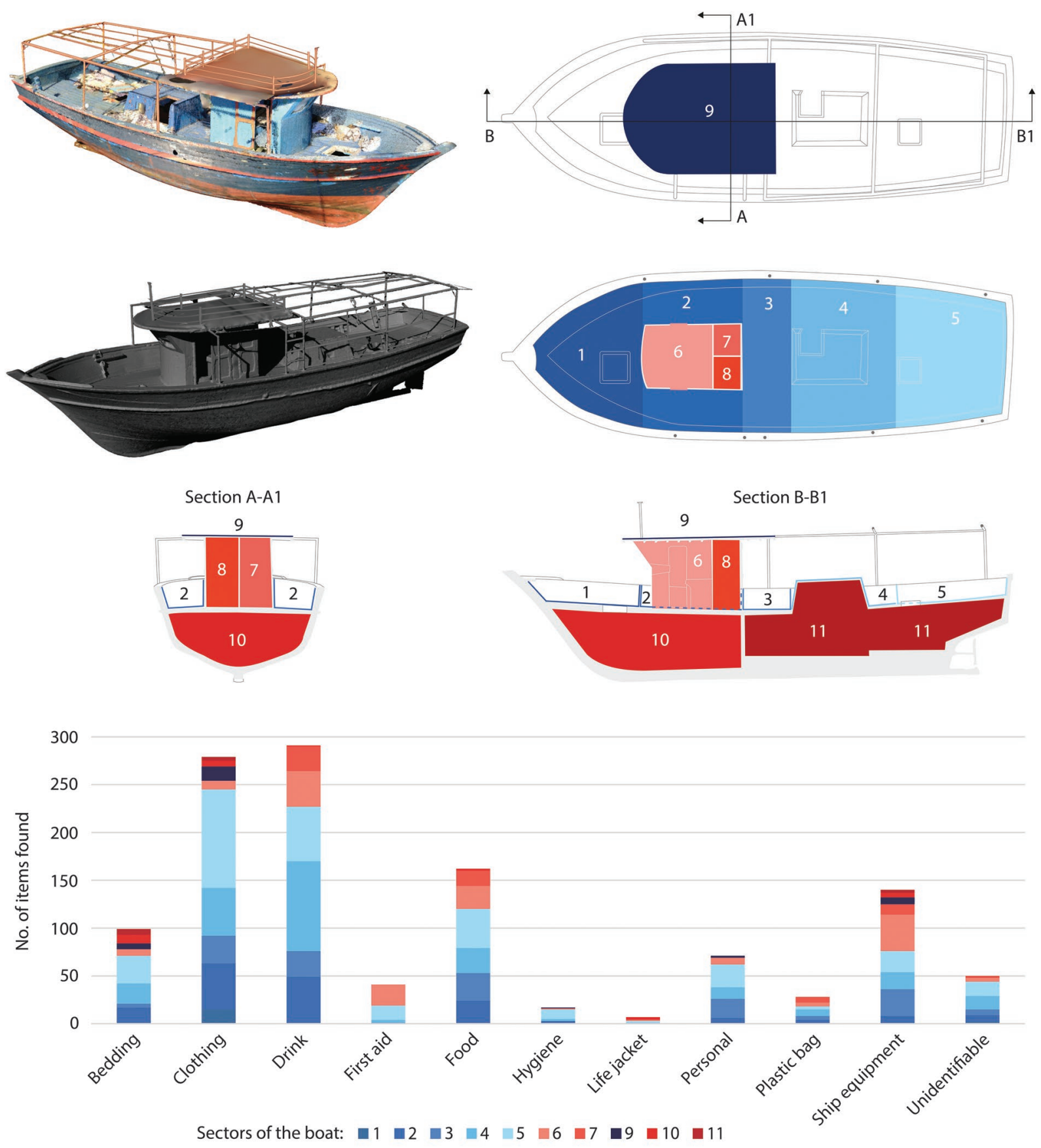

FIG. 5. Model of Boat \#179, with designated areas labeled numerically: sectors 1, 3, 4, 5 = fore and aft deck areas; sector $2=$ deck on either side of wheelhouse; sector $6=$ wheelhouse; sector 7 = storage compartment; sector $8=$ toilet (not recorded); sector $9=$ upper deck area; sector $10=$ forward hold; sector $11=$ aft hold and engine area. The histogram reflects object categories according to their recorded sector (with assistance of L. Hoffer and O. Tucker).

These features typically allow outflow of water off the canted deck; here, they were stuffed with wadded socks to keep the deck dry, preventing water from entering as the top-heavy vessel rolled. Below deck, a thick layer of cement was added between the frames in the bow and stern areas (sectors 10, $11 \mathrm{aft}$ ). This curious ballasting was pointed out to us by Savasta, who suggested it was a recent addition designed to lower the boat's center of gravity and allow additional stability given the greater than normal weight borne 

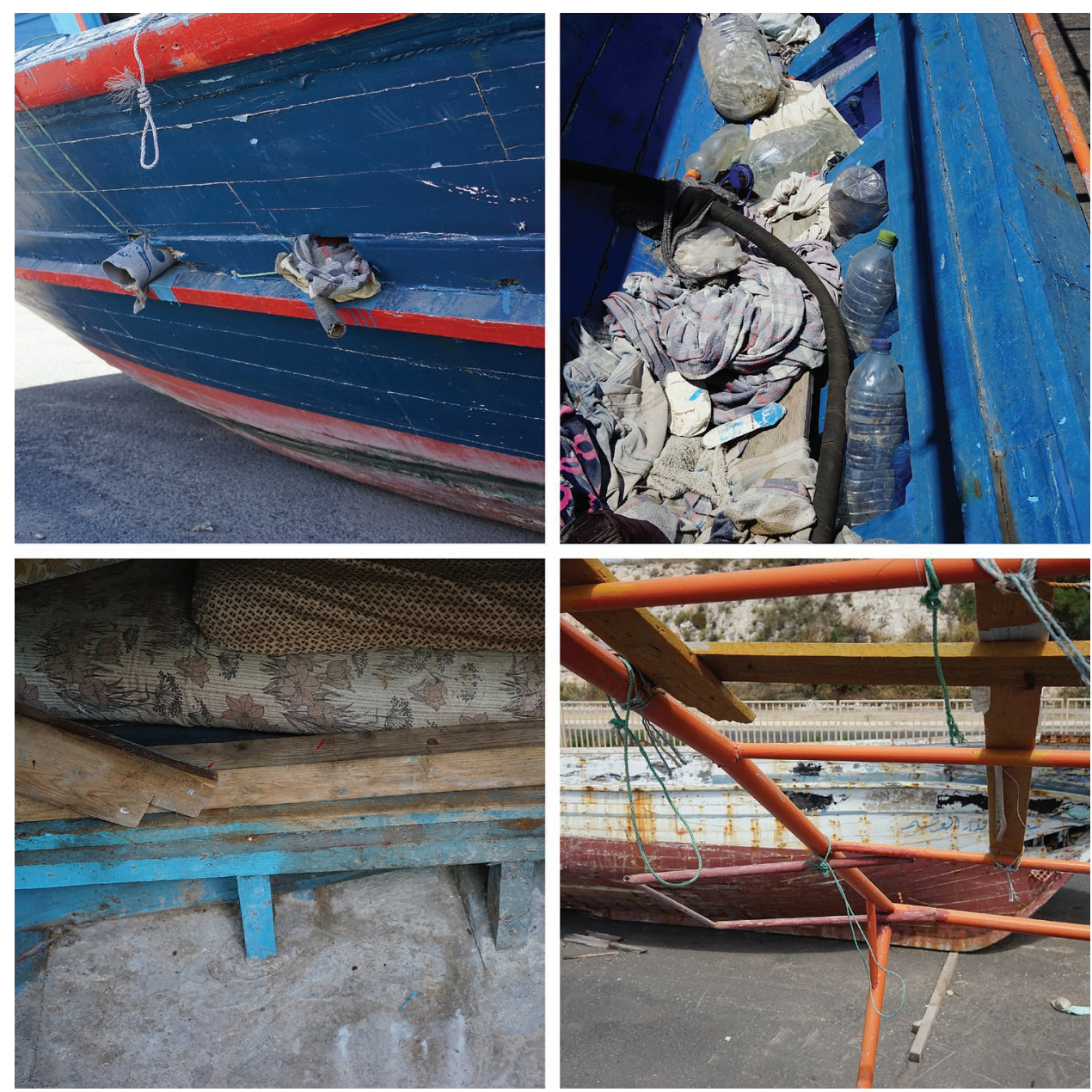

FIG. 6. Structural and use-wear adaptations to the traditional fishing boat include exhaust hoses to vent lower spaces, handholds attached to the canopy, cement ballasting between the interior frames, and intraframe spaces used as cubbies.

not only on the main deck but also on the improvised upper level above the wheelhouse. We cannot yet say with certainly whether the cement was a recent modification or part of inexpensive ballasting and antifouling practices among North African fishermen.

The boat's size places it somewhere on the larger end of the average range of small-scale seasonal fishing vessels in the central Mediterranean, and it might normally have been operated by a crew of 5-8 sailors engaged in single-day or short multiday fishing ventures; simply keeping the vessel moving under engine power could likely be accomplished by as few as 1-2 individuals. ${ }^{53}$ Such fishermen commonly exploit oceanic migratory fish species like tuna, swordfish,

${ }^{53}$ Morales-Nin et al. 2000, 205. and dolphinfish, though commercial overfishing has resulted in significant reductions to the profitability of small-scale industries. Recent enforcement of new sustainability initiatives has seen some local renewal of fish stocks, but their recovery is not yet assured or sufficiently widespread to rejuvenate local economic livelihoods. ${ }^{54}$ Friese and Ben-Yehoyada have explored the long-term connections between migrants and fishermen communities whose relationships reflect the shared impact of environmental degradation from climate change and overfishing. ${ }^{55}$ Whereas local Sicilian fishermen can be bought out of their livelihood through various European Union initiatives, North

\footnotetext{
${ }^{54}$ Longo and Clausen 2011; Medley et al. 2021.

${ }^{55}$ Friese 2014; 2015; Ben-Yehoyada 2016; 2018.
} 
African fishing communities' opportunities more often come from selling their vessels, including to those who pass them along to traffickers. ${ }^{56}$ At the same time, those who continue fishing from either shore can find themselves as the first line of rescue. While customary laws of the sea obligate sailors to assist those in distress, such activity may put them at odds with local authorities. ${ }^{57}$

\section{The Vessel's Material Assemblage}

At the scale of the object, our finds reveal what was left behind on the boat at the moment of interception by Italian authorities. ${ }^{58}$ Nearly 1,200 documented objects, ranging from clothing and bedding to food, water, and medical and hygiene supplies, reflect the uneven mix of genders, ages, and background experiences recorded in UNHCR and IOM data. Their distributions across the vessel (see fig. 5) hint at shipboard inequalities and ad hoc communities, including among those unaccustomed to the sea. The greatest variety of consumed food items and cigarettes, for example, was found in the wheelhouse (sector 6). ${ }^{59}$ Medical supplies were also recorded here, designating the area as a space for care: assorted packets and solutions of pain relievers, antinauseals, antidiarrheals, and broad-spectrum antibiotics, all within their use dates. The assemblage also includes medical tape, scissors, IV tubing, bottles of saline solution, surgical suture, and glass vials of IV-administered metaclopramide and oxytocin, both used for the management of labor and delivery ${ }^{60} \mathrm{Bulk}$

\footnotetext{
${ }^{56}$ Kingsley 2015.

${ }^{57}$ This situation is explored in Emmanuele Crialese's 2011 film Terraferma. Celik Rappas and Phillis (2020, 44-47) explore the film's representation of changing border regimes that criminalize humanitarian rescue, while critiquing the victimization of migrants and the ennobling of the Italian protagonists.

${ }^{58}$ According to Caltagirone, migrants are initially separated from their personal items and phones, but these items are returned following the registration process; items confiscated from individuals identified as traffickers are retained for investigative purposes.

59 Queirolo Palmas (2020, 864-69) and Ricard-Guay (2018) describe a blurring of categorization between migranttransporter-trafficker, citing the operation of boats by migrants with perceived nautical skills or in exchange for free passage.

${ }^{60}$ While all but the oxytocin have multiple possible purposes, together these pharmaceuticals suggest that the boat's preparations included the possibility of childbirth on board. We are grateful to A.T. Flanigan and C. Barthol for a medical perspective on these items.
}

food and drink and their plastic or cardboard packaging, on the other hand, are common finds across the various deck spaces and seemingly far more frequent on the main deck than in the confined areas of the hold. Abandoned clothing and bedding items are most common on the stern deck (sectors 4,5 ), likely reflecting the densest concentration of people, as well as the staging ground for eventual disembarkation as evident in images from news reports of the boat's arrival at the port. Few items that could be definitively connected to women or children were found on the bow area or the raised deck above the wheelhouse (sectors 1, 9), perhaps because these areas were seen as more hazardous. The histogram displays less data from the hold of the vessel and the toilet area, which were not explored as thoroughly for reasons noted above.

Nearly 100 blankets, sheets, sarongs, and scarves point to a wide range of uses for this simple and adaptable rectangular shape (fig. 7). Many sheets and towels with surviving labels are of a similar pale yellow-green color, branded with the name of a Turkish trading company; these perhaps reflect the availability of goods in detention centers, or accessible to migrants in Misrata more generally. Within this category, the most common items left behind are dozens of synthetic blankets in a variety of weights and sizes. Their corners are stretched, knotted, or tied with bits of string or fishing line, revealing changing functions along this and other segments of the journey: floor covers and pillows for sleeping, scarves for warmth, modesty, or protection from surveillance, shade providers, space markers and partitions, baby slings, rucksacks and other containers, and surely many more purposes. Foil rescue blanket wrappers and paper masks that recall the vessel's interception by Italian authorities add yet another layer to the story.

Scattered throughout the main deck and lower hold (sectors 3, 5, 6, 10) were only seven life jackets (fig. 8). Likely used on this last voyage as padding and pillows rather than as rescue devices, their total suggests equipment left over from the boat's original fishermen rather than individual preparations for the migrant journey. The numbers mark a striking divergence from the huge piles of orange life jackets washed ashore that have come to emblematize the shorter trip from Turkey to the Greek islands. ${ }^{61}$

\footnotetext{
${ }^{61}$ Tyrikos-Ergas 2016.
} 

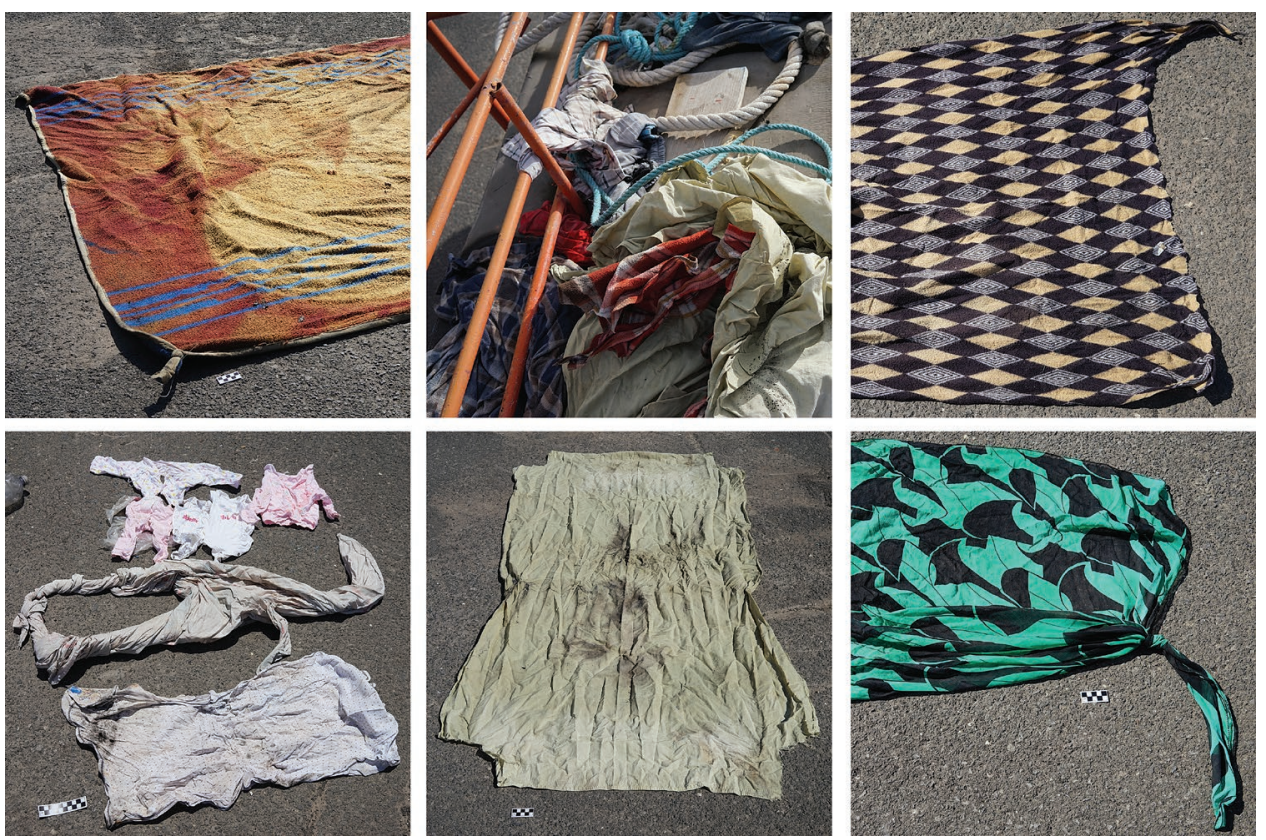

FIG. 7. Sheets, towels, blankets, scarves, sarongs, and other rectangular fabrics used for multiple purposes.
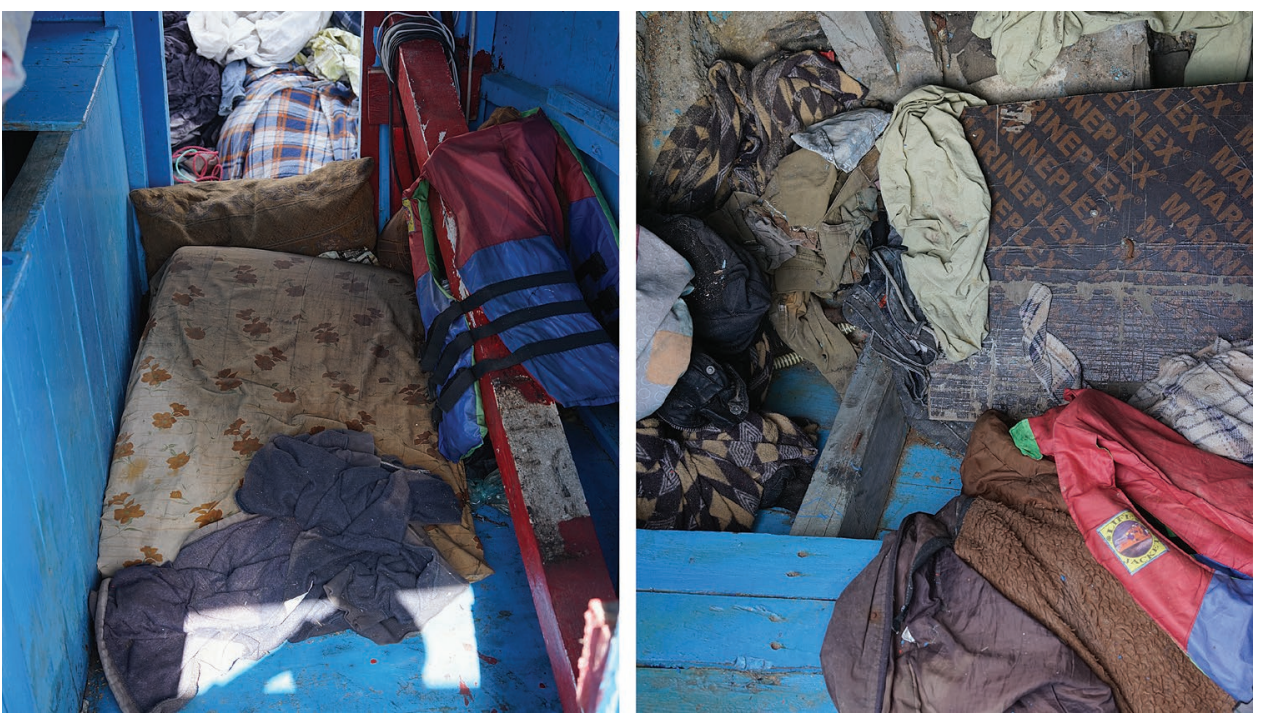

FIG. 8. Only seven life jackets were recorded, here used as padding and pillows; these were probably acquired during earlier stages of the boat's use.

Clothing reflects the global market, with brands ranging from imitation "Borssche" (Porsche) jeans and "Hike" (Nike) sneakers, complete with a modified swoosh logo, to international chains such as the Spanish Mango, Italian Diesel, or Swedish H\&M brands (fig. 9). Pants and jerseys sporting logos of an assortment of European football teams from Barcelona to
Paris to Munich reflect similar globalizing patterns. While it was not always possible to assign age or gender to common tank tops, T-shirts, pants, and long robes, such items were found in greater quantities than dresses, skirts, and leggings, or clothing in sizes and patterns suited for young children. These numbers are unsurprising given the high ratios of adult men to 

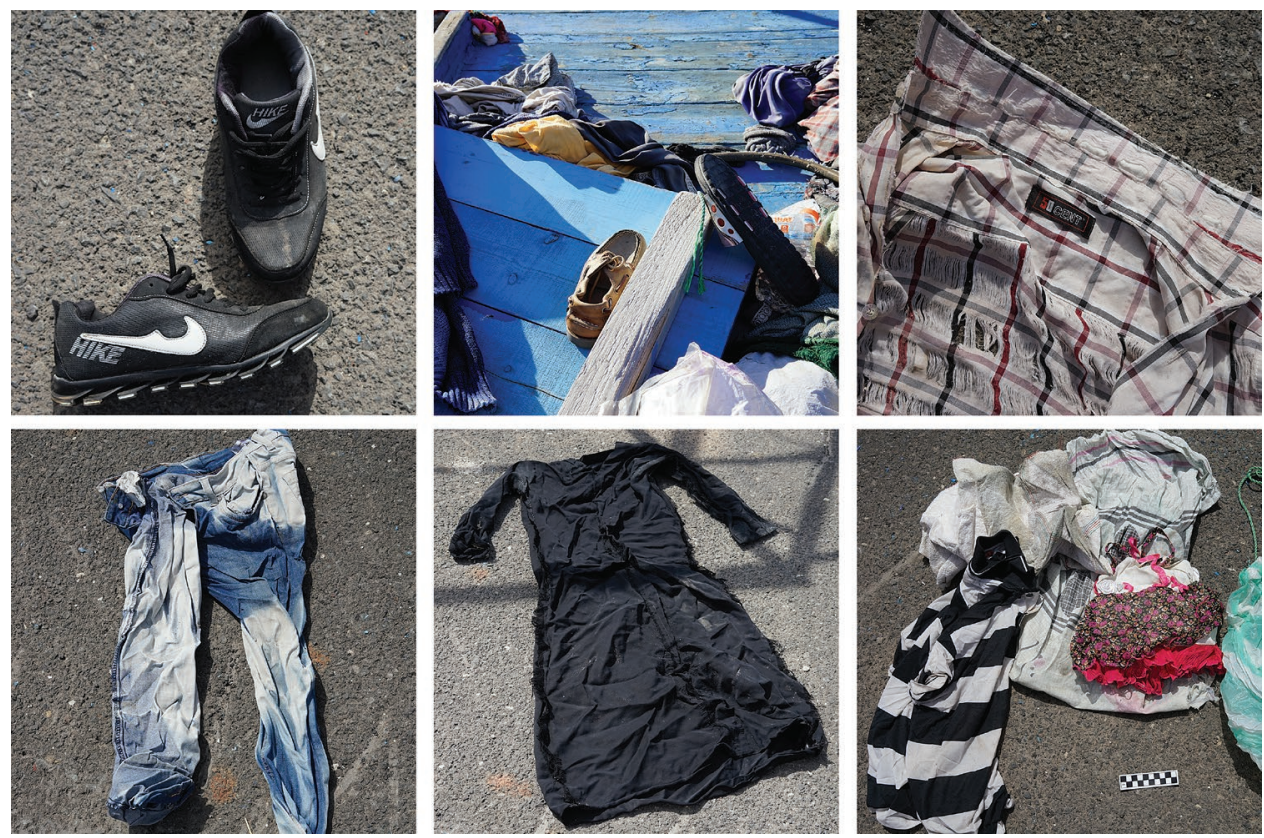

FIG. 9. Hastily removed clothing, reflecting an uneven mix of age and gender, recovered from all areas of the boat.

women and minors known to have been on board. ${ }^{62}$ Items were in varying states of repair: some looked nearly new, while others were heavily worn, frayed, torn, or mended. With the exception of a few plastic bags containing spare clothing, frequently in child sizes, the garments were most often turned inside out, and dried into stiff and salt-crusted shapes, wadded against wherever they had fallen on deck, likely reflecting a hurried discard and change to clean or dry clothing following interception and before disembarkation.

In the case of Sonoran Desert crossings, De León records diverse assemblages of backpacks, clothing, hygiene, cosmetics, and other personal items. ${ }^{63}$ These are attributed to a rapid changing process, designed to help migrants hide the fact that they have just crossed through the desert, and to discard evidence that could signal to authorities their status as undocumented. Here, when expected interception would make disguis-

\footnotetext{
${ }^{62}$ On Boat \#179, women and minors each comprised $15 \%$ of the total number on board; both figures are significantly higher than general 2017-19 statistics for boat arrivals to Italy (10\% women; $3 \%$ children), suggesting that larger boats may have been seen as safer than dinghies for women and children. See Malakooti and Fall 2020, 69.

${ }^{63}$ De León 2015, 191-92.
}

ing of migrant status impossible, inside-out clothing strewn unceremoniously on deck may be less a result of concealment than a desire finally to discard the damp and soiled garments that bear stains of the long journey, highlighting a moment of arrival and a new beginning. Our recording of approximately 50 pairs of pants, three skirts, seven dresses or robes, and more than 100 socks suggests that such a luxury was not available for a majority of the 264 migrants on board. Scattered finds of toothbrushes, toothpaste, hair gel, and other personal hygiene products suggest provisions assembled for an extended journey with many steps, rather than preparation for a discrete moment of transformation. Occasional discards of socks, hats, lighters, or other items marked with country names or other identifications (colors, flags) may attempt to mask clues of national identity that might provide evidence for later deportation: for example, a red, yellow, and green sock marked "Guinée," and a lighter with a crescent and star. ${ }^{64}$

Packaged croissant wrappers, orange-capped water bottles, and empty juice boxes, along with labeled cardboard boxes and plastic wrap retaining the shape

\footnotetext{
${ }^{64}$ See also Blake and Schon 2019, 186.
} 
of multibottle packs may signal bulk provisions supplied or sold to migrants. More unique individual items - from bagged sugar, date paste, and processed cheese to toothbrushes and diapers-were often tucked away in knotted plastic bags hung from nails in the cubby areas described above between frames on the main deck (fig. 10). The $250 \mathrm{ml}$ juice boxes, in orange and mixed fruit cocktail flavors, were primarily of the Benghazi-based Zain brand; with these were discarded straws and multistraw strips, still encased in their plastic wrappers. Juice boxes were more frequently torn open for direct consumption than poked through the foil holes with straws. Half-liter water bottles, few of which still contained water, were primarily of the Misrata-based Rahaf brand, with occasional others in various sizes (Tunisian Melitti, Italian Roverella and Santa Maria) and three 6-liter bottles of Ukranian Kakhovka (two still more than half-full, one containing brown liquid); how this last group made its way to Misrata is not clear. Chocolate croissant wrappers named two primary companies: Altona Alhamra and Al Nakheel, both Tripoli-based, marked by brown and blue wrappers, respectively. Shelf-stable UHT milk containers, normally 1-liter, were found less frequently, as were boxes or foil wrappers from Egyptian Régal Picon cheese triangles, and a variety of biscuits and other sweets. Production and expiration dates on discarded food packaging indicate purchases made shortly before the journey. The prevalence of shelfstable convenience store foods probably reflects local availability in Misrata and provides few clues about the preferences or origins of their consumers. ${ }^{65}$

Though we imagine many of the containers from consumed items were tossed overboard following consumption by those close to the rails, certain other items seem often to have been retained for secondary use, including wrappers and water bottles, the latter at times serving as urine containers. The dark tea-colored liquid still retained in some bottles speaks to the dire scarcity of water on board. Even assuming that a significant percent of used water bottles and juice boxes were discarded into the sea, the approximately 300 bottles, boxes, caps, straws, and labels recorded on board raise doubt that the migrants received 2.5-3 liters of liquid

\footnotetext{
${ }^{65}$ Seitsonen et al. $(2018,149)$ observe a similar phenomenon in consumed provisions from abandoned cars on the FinnoRussian border.
}
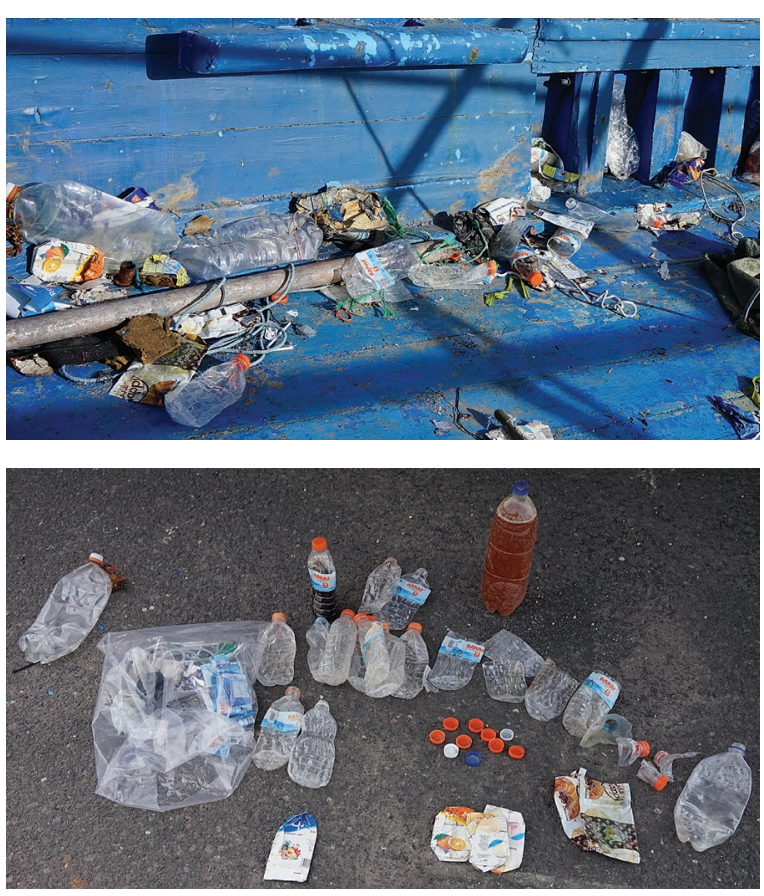

FIG. 10. Empty water bottles, juice boxes, and the wrappings from packaged pastries, purchased shortly in advance of the voyage.

per day, the quantity estimated by the World Health Organization as necessary for basic survival. ${ }^{66}$

A greater variety in type and brand of food items was found in the wheelhouse (sector 6). Comparatively high numbers of the same empty water bottles and juice boxes, plus tiny plastic espresso cups, scattered sunflower seed shells, discarded cigarette butts, and a grape juice bottle converted with a piece of plastic tubing into a water pipe attest to strikingly different patterns of consumption in this area. An empty box of calcium-enriched Munchy's Lexus chocolate crackers was perhaps obtained by one with greater access to movement and provisions. In the closet behind the wheelhouse (sector 7; fig. 11), two crates containing well-worn utensils and partly filled containers of cooking oil, lentils, spices, pasta, and jams (when dated, the items reveal production in 2017 or early 2018) recall earlier fishing ventures of one or a few days, when food may have been cooked onboard.

\footnotetext{
${ }^{66}$ World Health Organization 2011. This number for basic survival-level requirements includes liquid for drinking and food, but not hygiene or cooking.
} 


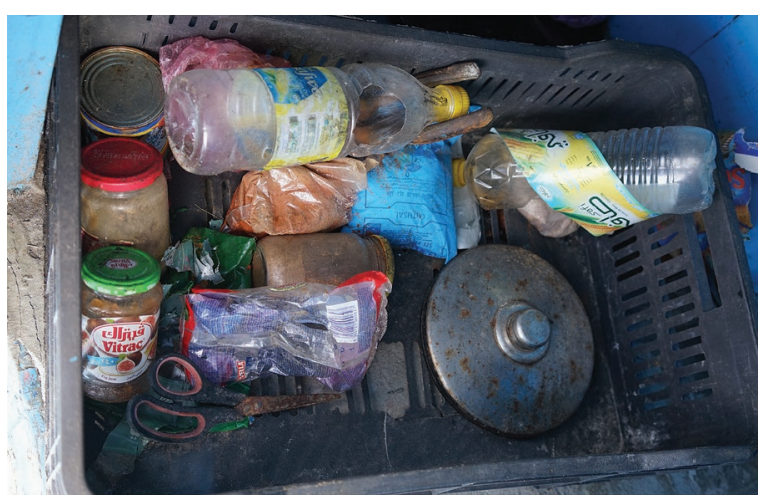

FIG 11. Cooking supplies found in a crate stored in a closet behind the wheelhouse.

On the back of a series of hand-lined paper scraps and salvaged cigarette packs from the pocket of a pair of men's black jeans in the stern of the vessel (sector 4), we found bilingual phrases in French and Eritrean Tigrinya, the latter also written in a Latin alphabet, and a list of phone numbers with a wide range of country codes from Mayotte in the Indian Ocean to France and Ukraine. These phrases and numbers may suggest intersecting networks of friendship, knowledge, payment demands, or trafficking routes. The single Carex condom from the same pants calls attention to gender inequalities and sexual violence by which these voyages and detentions are regularly marked. That these pants were found in the stern, abandoned together with other discarded clothing may suggest certain convergences in possessions and networks between traffickers and migrants. ${ }^{67}$ Loose fragments of similar recycled boxes, with numbers written in black and red pens, were found scattered around and behind the wheelhouse, along with the plastic card from which a SIM card for a satellite phone had been punched (sectors 2, 3, 6). The cigarette packs, all of American Legend brand, likely highlight the prevalence of goods smuggled into Libyan markets. ${ }^{68}$ Otherwise, pockets of pants and jackets were generally empty of valuables or personal items, suggesting either careful transfer,

\footnotetext{
${ }^{67}$ Campana 2018; also see Lucht 2012, 119-59, and RicardGuay 2018 for discussion of migrants as pilots of vessels crossing the central Mediterranean.

${ }^{68}$ Such "illicit white" brands are manufactured legitimately, in this case under the Greek Karelia label, but smuggled and consumed without customs duties, and together with other contraband and counterfeit products comprise the vast majority of cigarettes consumed in Libya; see KPMG 2017, with caveats.
}

even in the rush to change, or that few personal items remained in the care of their owners by this stage of the journey. ${ }^{69}$ Among the few finds we retrieved from pockets were certain specific medicines, including soluble packets of Uricol, for the treatment of urinary tract infections; scarce water supplies might render such medicinal regimens impossible to maintain, while creating a vicious cycle of illness.

Among the discarded clothing on the stern deck (sectors 4, 5), we also found a lost or abandoned passport photocopy, the lamination peeled off from an asylum seeker registration card but still retaining the ghostly imprint of personal data, and an assortment of Libyan dinars in small denominations: some torn into tiny pieces, another in the sewn-closed pocket of a pair of sweatpants. The passport, belonging to a 17-yearold male from Bangladesh, was issued in April 2017; the youth could not have departed before this acquisition date, but he may have been in transit for as many as 20 months by the time of the boat's interception. Similarly, the details of the asylum registration card, issued in May 2017 following arrival in February of that year, reflect a period of liminality long enough for the card to have expired after 18 months of validity. The removal of the lamination to destroy the paper card underneath may reflect responses to legal structures that allow individuals to seek asylum in only one country. Jumbled among juice boxes and medical supplies on the shelf below the wheelhouse window sat a leather cover removed from a Koran, inscribed in Arabic with a woman's name written in two different hands (fig. 12). Throughout North Africa, the verb haraqa (to burn) is used in colloquial speech also to indicate the act of border crossing; "burning the Mediterranean" carries an assumption of risk, loss, destruction, and potential rebirth in the space of diaspora. ${ }^{70}$ The purposeful destruction of documents - to avoid identification and repatriation, sacrificing the past for the future-appears similar to the obscuring of the boat's name and registration number. Such erasures are not uncommon on other vessels recently impounded in

\footnotetext{
${ }^{69}$ A similar dearth of personal items or "identity markers" was recorded by Blake and Schon $(2019,191-92)$, who suggest that "the relationship between possessions and identity changes and loosens in conditions of forced or undocumented displacement."

${ }^{70}$ Di Maio 2013, 43-45; Alexander-Nathani 2021, xxv, 120.
} 


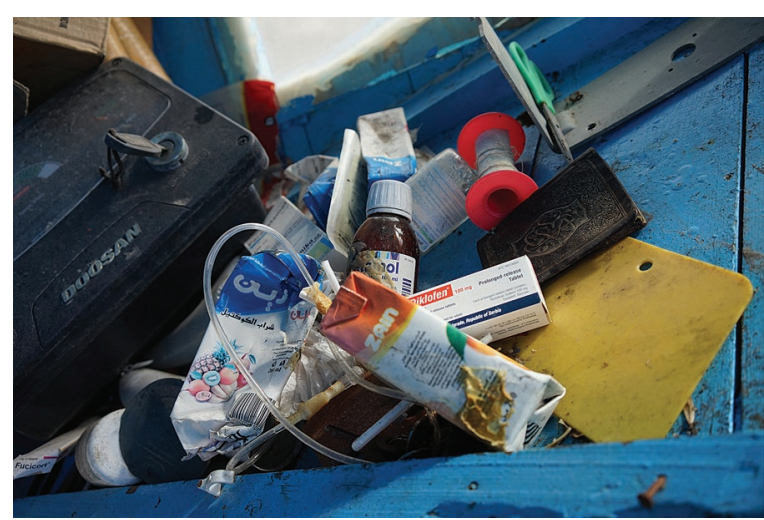

FIG. 12. The empty leather cover of a Koran, among juice boxes, medical supplies, and a putty spreader, on the shelf below the wheelhouse window.

the Pozzallo lot, where identifying information is destroyed even as prayers are preserved (fig. 13).

This repurposed boat and the systems of trafficking suggested by its material assemblage reveal certain differences from vessels of just a few years earlier, as recorded in Savasta's photographs. Some of the earlier voyages included significantly larger numbers of life jackets provided for or by each person on board (fig. 14). Neither on Boat \#179 nor on any of the other three boats under investigation at Pozzallo did we find more than a few life jackets, suggesting systems designed for the rapid and opportunistic transfer of migrants directly from confinement in so-called connection houses or detention centers to the shore, with fewer opportunities for individualized organization, preparation, or the negotiation of personal safety. ${ }^{71}$ Alternatively, in western Sicily, Blake and Schon have recorded the movements of small groups of migrants originating likely on the Tunisian coast. ${ }^{72}$ Here they found smaller craft, smaller groupings of primarily young men, and an apparent goal of evasion rather than interception. "Migrant-specific capital" in the form of coordinated knowledge for the crossing, along with social ties to individuals equipped to provide support and facilitate mobilities in the next stages of the journey, are seen as key to these movements, certain similarities to which can be observed in the lists of

\footnotetext{
${ }^{71}$ Aziz et al. $(2015,35-37)$ describe the long confinement of migrants in detention centers and connection houses, until they are brought to the sea for nighttime departure.

${ }^{72}$ Blake and Schon 2019, 192.
}

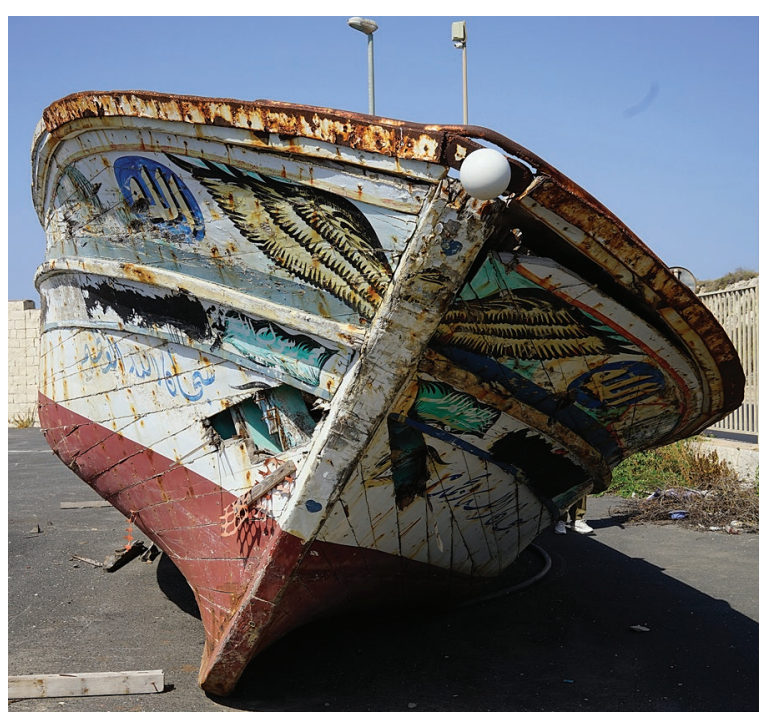

FIG. 13. Erasure of vessel names is common; on another boat in the Pozzallo lot, the name is erased but the prayers are preserved.

contacts found on Boat \#179. Comparative studies of boats, modifications, and abandoned materials across Sicily, on Pantelleria, Lampedusa, and Linosa, as well as those connected to eastern and western Mediterranean routes, will be important for future study of diachronic shifts and regional patterns of migration that respond to perpetually shifting border regimes and political agendas.

\section{COMPLICATING MEDITERRANEAN CONNECTIVITY}

Such analysis of different vessels and routes represents just one facet of the work classical archaeologists can do to engage with this challenging ephemeral heritage of contemporary Mediterranean mobility, and to situate it in a more reflexive, inclusive, and global context. The close reading of artifacts from these journeys may provide archaeologists with clues to distinguishing forced movements in the deep Mediterranean past, the material assemblages of which are more limited and equivocal; they may also require interpretations that recognize the layering of usages for single objects, the challenges of determining cultural identifiers in well-connected regions, the different journeys conducted by the same vessel, and the everyday objects lost to the environment of liminal landscapes. ${ }^{73}$ What

\footnotetext{
${ }^{73}$ See, e.g., Driessen 2018.
} 


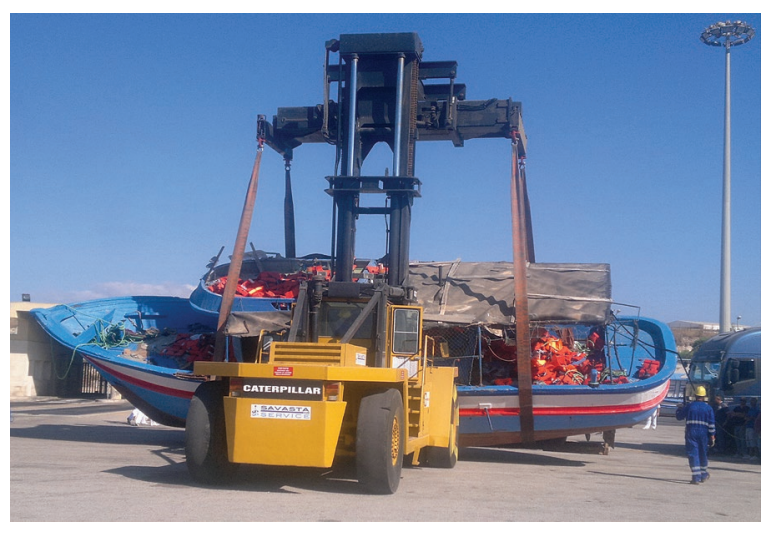

FIG. 14. Another boat in the Pozzallo lot, photographed upon its impoundment in 2014 but long since destroyed. This vessel held many life jackets (G. Savasta).

roles do different objects play in migrants' sustaining of connections to prior lives and forging of new lives? What adaptations to objects and structures might reveal transformations for new uses? Notwithstanding the challenges of analogy, such archaeology may shed new light on multivalent assemblages of interaction in the past, and throw into higher relief the full range of peoples and processes that are often flattened into the single final voyage of a wrecked ship or boiled down to generic explanations of migration, exchange, and interaction.

For the present work, the process of formal and informal recording becomes a fundamental tool in reframing such materials as heritage. While the objects from Boat \#179 were preserved only through documentation, efforts by the Porto M project on Lampedusa offer a productive model for stewardship of the collected remnants from boats washed ashore, from hull timbers and life jackets to shoes and pots. Described as a project of salvage from abandoned boats by the local collective Askavusa, the assembling of material testimonies preserves tangible reminders of the maritime passage and contributes to what Mazzara sees as a "process of subjectification of the migratory experience, where from debris, waste and anonymous mass, migrants eventually become subjects of power, subverting the dominant discourse revolving around their invisibility as 'boat people." " 74 Similarly the exhibit Transient Matter: Assemblages of Migration in the Mediterranean in Brown University's Haffenref-

\footnotetext{
${ }^{74}$ Mazzara 2018, 153-54.
}

fer Museum of Anthropology combines archaeological materialities from Aegean crossings with objects used in detention camps and art produced by people temporarily residing there. ${ }^{75}$ Such presentations place collaborative engagement with assemblages alongside migrant visibility, activism, and a subversion of the dominant discourse around the exhibition of objects representing more comfortable pasts; they work to engage communities in an ongoing archaeology of care.

In amplifying often muted voices, such heritage production reflects the opposite approach from Christoph Büchel's "Barca Nostra" at the 2019 Venice Biennale, which followed a trajectory parallel to (if ultimately rather different from) that of Pozzallo Boat \#179, from fishing boat to migrant vessel to heritage object. The exhibit involved the display at the Arsenale of a $20 \mathrm{~m}$ fishing boat that sank in 2015, killing the majority of the 800 on board in one of the deadliest migrant wrecks recorded. The ship was recovered by the Italian navy in 2016, and a team of pathologists and forensics experts embarked on a project of victim identification that continues today. ${ }^{76}$ But labels designed to explain the ship's traumatic history were deemed by Büchel as disruptive of "the process by which questions are raised, assumptions are made, intentions are projected onto the project, and a meaningful debate ensues;" ${ }^{\prime 7}$ this resulted in a sanitized and decontextualized art-relic. ${ }^{78}$ An attempt by American-Ethiopian artist Tsedaye Makonnen to contextualize this exploitation of tragedy and racialized oppression as a space of memory was met with intervention, leaving tourists

\footnotetext{
${ }^{75}$ For the online exhibit at Brown's Haffenreffer Museum, see https://blogs.brown.edu/transientmatter/. Other examples include the Undocumented Migration Project's multivenue exhibit State of Exception / Estado de Excepción, with its display of objects recovered from the Sonoran Desert (see Barnes et al. 2013), and the London exhibition, Sink Without Trace (see Mazzara and Ramsay 2019), which brought public visibility to the subject of migrant deaths at sea through a mix of art, found objects, and photographic documentation, including Lucy Wood's floating art installation of the rescued north African migrant boat $\mathrm{T} 06411$.

${ }^{76}$ M'charek and Casartelli 2019.

${ }^{77}$ The statement from Büchel's team can be found in Ruiz 2019.

${ }^{78}$ Wilson $(2019,73)$ bitingly describes the exhibit as "art, that great sucking vortex of relational-aesthetic annulment hedged with the propitiatory power of the relic"; see also Paynter and Miller 2019 for further critique of the exhibit.
} 
free to gawk at an Instagram-ready spectacle. ${ }^{79} \mathrm{~A}$ similarly decontextualized display of the bow of a wooden migrant boat was erected in Marzamemi's central piazza in 2014; notionally designed as a monument of memory, the lack of explanation raised multiple challenges for local reception. ${ }^{80}$

The framework of ships from periods other than antiquity as markers of multifaceted connections sits somewhat uneasily in local Sicilian conceptions of heritage. Community-based survey in Marzamemi undertaken in 2016 with assistance of Alessandro Arangio from the University of Messina, as well as interviews with residents and summer visitors conducted by MMHP team member Madeleine Ota with Gea Fazzino, have revealed the primacy of the classical Greek past in the traditional heritage discourse, along with an awareness of the sea as an ongoing source of sustenance, communication, tradition, and relationships. ${ }^{81}$ To this end, maritime archaeology provides a framework for engagement with the broad spectrum of connectivity and mobility. The materiality of ancient and historic pasts is visible, for example, in the multiple marble-carrying wrecks found along the southeast coast or bronze rams from warships found off the Egadi islands; it can be seen in the physical and intangible heritage of tuna fishing from ancient and historic fish-processing installations at Vendicari, recently retired fishing vessels in Marzamemi and Portopalo, or the stories of the last fishermen of the mattanza, the traditional communal net fishing. ${ }^{82}$ Marzamemi's Museum of the Sea was formally established in a repurposed 19th-century winery, Palmento di Rudini, around the beginning of investigations of the Late An-

\footnotetext{
${ }^{79}$ In an Instagram post describing the event (www.instagram. $\mathrm{com} / \mathrm{p} / \mathrm{BxXd} 3 \mathrm{Bfls} \mathrm{Q} 2)$, Makonnen describes: "During my performance the Venice Biennale and police created a blockade around the boat that $800+$ migrants who look like me and other Africans drowned in." A performance video titled When Drowning Is the Best Option: Astral Sea I can be found at https:// addisfineart.com/video/13-when-drowning-is-the-best -option.-astral-sea/. In April 2021, La Repubblica reported on the boat's return to Augusta, Sicily, to serve as a local monument for reflection on those who cross the sea (Di Feo 2021); critique by Salerno 2018 of the display of the Albanian boat Katër i Radës in Otranto offers a valuable warning.

${ }^{80}$ See Moncado 2014 for a photograph and critique of the boat in the Marzamemi piazza, with its spray-painted phrasing of "ovunque proteggi" (protect everywhere).

${ }^{81}$ Ota 2018, 59-62.

${ }^{82}$ Repola et al. 2020; Royal and Tusa 2020; Leidwanger et al.2021a.
}

tique shipwreck as a place for the community to engage with the cultural and natural history of the sea. But even before its official designation, the space had provided an informal repository for maritime objects, ranging from coral-encrusted amphoras and fossils to wooden fish traps and military gas masks. Today, it offers a unique challenge and opportunity to center these diverse and entangled histories of movement that connect to the very frameworks of Mediterranean mobility. ${ }^{83}$

The diverse assemblages of migrant vessels provide a powerful tool for considering contemporary interactions across the central Mediterranean in tandem with more traditional forms of local maritime heritage. As we continue to do the work of understanding this data and building a broader study of regional and temporal variation in its materiality, we are working to involve migrant communities in making visible the structures that have contributed to this "heritage from below." Grounding entangled pasts and presents of different mobilities in the archaeological record helps to complicate popular conceptions of maritime heritage and in turn top-down adjudications of movement that have served to build barriers across a sea more commonly celebrated in historical discourse for its bridges. To take seriously the multifaceted long-term connectivity advanced by Horden and Purcell requires that classical archaeologists bring a reflexive lens to the ongoing entanglement of different mobilities and their disruptions across these waters. An archaeology of care evoked by such ephemeral assemblages acknowledges the many unfinished histories of variable and unequal access to Mediterranean mobility.

\author{
Elizabeth S. Greene \\ Department of Classics \\ Brock University \\ St. Catharines, Ontario, Canada \\ egreene@brocku.ca \\ Justin Leidwanger \\ Department of Classics \\ Stanford University \\ Stanford, California \\ jleidwa@stanford.edu \\ Leopoldo Repola \\ Department of Humanities \\ Suor Orsola Benincasa University \\ Naples, Italy \\ repolaleopoldo@gmail.com
}

\footnotetext{
${ }^{83}$ Leidwanger et al. 2021b, 48-51.
} 


\section{Works Cited}

Agbamu, S. 2019. "Mare Nostrum: Italy and the Mediterranean of Ancient Rome in the Twentieth and Twenty-First Centuries." Fascism 8:250-74.

Alexander-Nathani, I. 2021. Burning at Europe's Borders: An Ethnography on the African Migrant Experience in Morocco. Oxford: Oxford University Press.

Andersson, R. 2014. Illegality, Inc.: Clandestine Migration and the Business of Bordering Europe. Oakland: University of California Press.

Arnaud, P. 2005. Les routes de la navigation antique: Itinéraires en Méditerranée. Paris: Errance.

Atalay, S. 2020. "An Archaeology Led by Strawberries.” In Archaeologies of the Heart, edited by K. Supernant, J.E. Baxter, N. Lyons, and S. Atalay, 253-69. Cham, Switzerland: Springer.

Aziz, N.A., P. Monzini, and F. Pastore. 2015. The Changing Dynamics of Cross-border Human Smuggling and Trafficking in the Mediterranean. Rome: Istituto Affari Internazionali.

Barnes, R., J. De Leòn, and A. Krugliak. 2013. State of Exception: An Exhibition of the Undocumented Migration Project. Online exhibition catalogue. Ann Arbor: University of Michigan Institute for the Humanities. https://issuu.com/ humin/docs/state_of_exception.

Ben-Yehoyada, N. 2011. "Dead Reckoning or the Unintended Consequence of Clueless Navigation." 31: Das Magazin des Instituts für Theorie 16/17:104-13.

. 2016. "Follow Me and I Will Make You Fishers of Men': The Moral and Political Scales of Migration in the Central Mediterranean." JRAI 22(1):183-202.

_. 2018. "Time at Sea, Time on Land: Temporal Horizons of Rescue and Refuge in the Mediterranean and Europe." In Migration, Temporality, and Capitalism, edited by P.G. Barber and W. Lem, 63-79. Cham, Switzerland: Palgrave Macmillan.

Blake, E., and R. Schon. 2019. "The Archaeology of Contemporary Migrant Journeys in Western Sicily." JMA 32(2): 173-94.

Bounia, A. 2020. "Museums, Activism, and the 'Ethics of Care': Two Museum Exhibitions on the Refugee 'Crisis' in Greece in 2016." In Heritage Discourses in Europe: Responding to Migration, Mobility, and Cultural Identities in the Twenty-First Century, edited by L. Colomer and A. Catalani, 39-52. Leeds: Arc Humanities Press.

Braudel, F. 1972. The Mediterranean and the Mediterranean World in the Age of Philip II. Translated by S. Reynolds. New York: Harper Colophon Books. Original edition, Paris: Colin, 1949.

Broodbank, C. 2013. The Making of the Middle Sea: A History of the Mediterranean from the Beginning to the Emergence of the Classical World. Oxford: Oxford University Press.

Cabot, H. 2019. "The Business of Anthropology and the European Refugee Regime.” American Ethnologist 46(3): 261-75.

Campana, P. 2018. "Out of Africa: The Organization of Migrant Smuggling Across the Mediterranean.” European Journal of Criminology 15(4):481-502.
Caraher, W. 2019. "Slow Archaeology, Punk Archaeology, and the 'Archaeology of Care.” EJA 22(3):372-85.

Caraher, W., B. Weber, and R. Rothaus. 2018. "Lessons from the Bakken Oil Patch." In The New Nomadic Age: Archaeologies of Forced and Undocumented Migration, edited by Y. Hamilakis, 87-96. Sheffield: Equinox.

Carney, M.A. 2020, 12 November. "No Crisis Is an Island: On Migration, Pandemic, and Everyday Struggles in Sicily." American Ethnologist Online. https://americanethnolo gist.org/features/pandemic-diaries/introduction-interse cting-crises/no-crisis-is-an-island-on-migration-pandem ic-and-everyday-struggles-in-sicily.

2021. Island of Hope: Migration and Solidarity in the Mediterranean. Oakland: University of California Press.

Celik Rappas, I.A., and P.E. Phillis. 2020. “Do the Right Thing': Encounters with Undocumented Migrants in Contemporary European Cinema." Studies in European Cinema 17(1):36-50.

Cook, M.R., and A.E. Potter. 2018. "Unfinished Geographies: Women's Roles in Shaping Black Historical Counter Narratives." In After Heritage: Critical Perspectives on Heritage from Below, edited by H. Muzaini and C. Minca, 10-29. Northampton: Edward Elgar.

Crawley, H., and D. Skleparis. 2018. "Refugees, Migrants, Neither, Both: Categorical Fetishism and the Politics of Bounding in Europe's 'Migration Crisis.'” Journal of Ethnic and Migration Studies 44(1):48-64.

De León, J. 2015. The Land of Open Graves: Living and Dying on the Migrant Trail. Photographs by M. Wells. Berkeley: University of California Press.

De León, J., and C. Gokee. 2018. "Lasting Value? Engaging with the Material Traces of America's Undocumented Migration 'Problem."' In Cultural Heritage, Ethics and Contemporary Migrations, edited by C. Holtorf, A. Pantazatos, and G. Scarre, 70-86. London: Routledge.

De León, J., C. Gokee, and A. Forringer-Beal. 2015. “'Disruption,' Use Wear, and Migrant Habitus in the Sonoran Desert." In Migration and Disruptions: Toward a Unifying Theory of Ancient and Contemporary Migrations, edited by B.J. Baker and T. Tsuda, 145-78. Gainesville: University Press of Florida.

Dickson, A.J. 2021a. “The Carceral Wet: Hollowing Out Rights for Migrants in Maritime Geographies." Political Geography 90:102475.

_.2021b. "Mobility Control in Ungovernable Spaces: Cultivating the Mediterranean's Fatal Materiality." Environment and Planning C: Politics and Space 39(5):993-1010.

Di Feo, G. 2021, 16 April. "Migranti, la nave della strage torna in mare." La Repubblica. www.repubblica.it/crona ca/2021/04/16/news/migranti_la_nave_della_strage_ torna in mare-296724475.

Di Maio A. 2013. "The Mediterranean, or Where Africa Does (Not) Meet Italy: Andrea Segre's A Sud di Lampedusa (2006)." In The Cinemas of Italian Migration: European and Transatlantic Narratives, edited by S. Schrader and D. Winkler, 41-52. Newcastle upon Tyne: Cambridge Scholars Publishing.

Driessen, J., ed. 2018. An Archaeology of Forced Migration: 
Crisis-Induced Mobility and the Collapse of the 13th c. BCE Eastern Mediterranean. Aegis 15. Louvain-La-Neuve: Presses Universitaires de Louvain.

Edwards, A. 2016, 11 July. “UNHCR Viewpoint: 'Refugee' or 'Migrant' - Which Is Right?” UNHCR: News and Stories. www.unhcr.org/uk/news/latest/2016/7/55df0e556/un hcr-viewpoint-refugee-migrant-right.html.

Friese, H. 2014. Grenzen der Gastfreundschaft: Die Bootsflüchtlinge von Lampedusa und die europäische Frage. Bielefeld: Transcript.

_.2015. “Thalassographies of Departure, Disaster and Rescue: Fishermen and Undocumented Mobility.” Etnofoor 27(1):13-36.

Gokee, C., H. Stewart, and J. De León. 2020. "Scales of Suffering in the US-Mexico Borderlands." International Journal of Historical Archaeology 24:823-51.

González-Ruibal, A. 2008. "Time to Destroy: An Archaeology of Supermodernity." CurrAnthr 49(2):247-79.

2019. An Archaeology of the Contemporary Era. New York: Routledge.

Hamilakis, Y. 2018. "Archaeologies of Forced and Undocumented Migration." In The New Nomadic Age: Archaeologies of Forced and Undocumented Migration, edited by Y. Hamilakis, 1-19. Sheffield: Equinox.

Held, V.2006. The Ethics of Care: Personal, Political, and Global. New York: Oxford University Press.

Horden, P., and N. Purcell. 2000. The Corrupting Sea: A Study of Mediterranean History. Malden: Blackwell.

IMREF (Independent Monitoring, Rapid Research and Evidence Facility). 2020. "Full Report: Exploring the Impact of COVID-19 on the Vulnerabilities of Migrants on the Central Mediterranean Route." www.integrityglobal.com/ wp-content/uploads/20200727_imref_impact-of-covid -19-on-migrants-part-2_executive-summary.pdf.

Indelicato, S.D.M. 2020, 15 May. “Tra barchini e carrette del mare: L'invasione di sbarchi fantasma." Il Giornale. www. ilgiornale.it/news/cronache/pericolo-ritorno-degli-sbar chi-fantasma-1862632.html.

IOM (International Organization for Migration). 2018, 27 November. "Mediterranean Migrant Arrivals Reach 106,269 in 2018; Deaths Reach 2,119.” Press release. www.iom.int/news/mediterranean-migrant-arrivals -reach-106269-2018-deaths-reach-2119.

Janes, R.R., and R. Sandell. 2019. "Posterity Has Arrived: The Necessary Emergence of Museum Activism.” In $\mathrm{Mu}$ seum Activism, edited by R.R. Janes and R. Sandell, 1-21. New York: Routledge.

Kiddey, R. 2017. Homeless Heritage: Collaborative Social Archaeology as Therapeutic Practice. Oxford: Oxford University Press.

_2018. "From the Ground Up: Cultural Heritage Practices as Tools for Empowerment in the Homeless Heritage Project." International Journal of Heritage Studies 24(7):694-708.

. 2019. "Reluctant Refuge: An Activist Archaeological Approach to Alternative Refugee Shelter in Athens (Greece).” Journal of Refugee Studies 33(3):599-621.
Kingsley, P. 2015, 24 April. “Libya’s People Smugglers: Inside the Trade That Sells Refugees Hopes of a Better Life." The Guardian. www.theguardian.com/world/2015/apr/24/ libyas-people-smugglers-how-will-they-catch-us-theyll -soon-move-on.

KPMG. 2017,26 July. "Illicit Cigarette Trade in the Maghreb Region.” Report prepared by KPMG LLP for Philip Morris International Management SA. www.pmi.com/ resources/docs/default-source/pmi-sustainability/re port-on-the-illicit-cigarette-trade-in-the-maghreb-region. pdf?sfvrsn=67a69ab5_2.

Leidwanger, J. 2013. "Opportunistic Ports and Spaces of Exchange in Late Roman Cyprus." Journal of Maritime Archaeology 8:221-43.

. 2020. Roman Seas: A Maritime Archaeology of Eastern Mediterranean Economies. New York: Oxford University Press.

Leidwanger, J., E.S. Greene, and A. Donnelly. 2021a. "The Sixth-Century CE Shipwreck at Marzamemi.” AJA 125(2): 283-317.

Leidwanger, J., E.S. Greene, L. Repola, and F. Sgroi. 2021 b. "The Marzamemi Maritime Heritage Project: From the Seabed to the Museum and Beyond." In Trinacria, "An Island Outside Time": International Archaeology in Sicily, edited by C. Prescott, A. Karivieri, P. Campbell, K. Göransson, and S. Tusa, 45-53. Oxford: Oxbow.

Leonard, J.R. 2021. "Reflections on Coves, Carobs and a Diachronic Coastal Approach to the Roman Cypriot Maritime Economy." In All Things Cypriot: Studies on Ancient Environment, Technology, and Society in Honor of Stuart Swiny, edited by Z. Chovanec and W. Crist, 201-17. ASOR Archaeological Reports 28. Alexandria: American Society of Overseas Research.

Longo, S.B., and R. Clausen. 2011. "The Tragedy of the Commodity: The Overexploitation of the Mediterranean Bluefin Tuna Fishery." Organization and Environment 24(3):312-28.

Lucht, H. 2012. Darkness Before Daybreak: African Migrants Living on the Margins in Southern Italy Today. Berkeley: University of California Press.

Malakooti, A., and C. Fall. 2020. Migration Trends Across the Mediterranean: Piecing Together the Shifting Dynamics. Global Initiative Against Transnational Organized Crime and Clingendael: Netherlands Institute of International Relations.

Mazzara, F. 2018. "Objects, Debris and Memory of the Mediterranean Passage: Porto $M$ in Lampedusa." In Border Lampedusa: Subjectivity, Visibility and Memory in Stories of Sea and Land, edited by G. Proglio and L. Odasso, 153-73. London: Palgrave Macmillan.

Mazzara, F., and M. Ramsay. 2019. Sink Without Trace: Exhibition on Migrant Deaths at Sea. London, P21 Gallery, 13 June-13 July 2019. www.sinkwithouttrace.com/post/ sink-without-trace-catalogue.

McGuire, R.H. 2020. "The Materiality and Heritage of Contemporary Forced Migration.” Annual Review of Anthropology 49(1):175-91. 
M'charek, A., and S. Casartelli. 2019. "Identifying Dead Migrants: Forensic Care Work and Relational Citizenship." Citizenship Studies 23(7):738-57.

Medley, P.A.H., J. Gascoigne, and G. Scarcella. 2021. An Evaluation of the Sustainability of Global Tuna Stocks Relative to Marine Stewardship Council Criteria (Version 8): ISSF Technical Report 2021-01. Washington, D.C.: International Seafood Sustainability Foundation. https://iss-foundation. org/knowledge-tools/technical-and-meeting-reports/ download-info/issf-2021-01-an-evaluation-of-the-sust ainability-of-global-tuna-stocks-relative-to-marine-stewa rdship-council-criteria/.

Meskell, L. 2002. "Negative Heritage and Past Mastering in Archaeology.” Anthropological Quarterly 75(3):557-74.

2018. A Future in Ruins: UNESCO, World Heritage, and the Dream of Peace. New York: Oxford University Press.

Moncado, T.2014, 30 December."Ve le do io le pagelle... diamo i numeri tra Pachino, Portopalo e Marzamemi." Gazzetta del Mediterraneo. www.gazzettadelmediterraneo.it/ ve-le-io-le-pagelle-diamo-numeri-tra-pachino-portopalo -e-marzamemi-di-turi-moncada/.

Morales-Nin, B.L. Cannizzaro, E. Massuti, A. Potoschi, and F. Andaloro. 2000. "An Overview of the FADs Fishery in the Mediterranean Sea." In Pêche thonière et dispositifs de concentration de poissons: Colloque Caraibe-Martinique, Trois-Îlets, 15-19 octobre 1999, edited by J.-Y. Le Gall, P. Cayré, and M. Taquet, 184-207. Plouzané: Institut Français de Recherche pour l'Exploitation de la Mer. https:// archimer.ifremer.fr/doc/00042/15286/.

Muzaini, H., and C. Minca. 2018. "Rethinking Heritage, But 'From Below."' In After Heritage: Critical Perspectives on Heritage from Below, edited by H. Muzaini and C. Minca, 1-21. Northampton: Edward Elgar.

Olivieri, L., D. Mazzarelli, B. Bertoglio, et al. 2018. "Challenges in the Identification of Dead Migrants in the Mediterranean: The Case Study of the Lampedusa Shipwreck of October 3rd 2013." Forensic Science International 285:121-28.

Ota, M. 2018. "Classical Heritage in Regional Contexts: An Ethnographic Inquiry into Perceptions of Cultural Heritage in Southeastern Sicily." Undergraduate honors thesis in archaeology, Stanford University.

Paynter, E., and N. Miller. 2019, 22 September. "The White Readymade and the Black Mediterranean: Authoring 'Barca Nostra”' Los Angeles Review of Books. https:// lareviewofbooks.org/article/the-white-readymade-and -the-black-mediterranean-authoring-barca-nostra/.

Perkowski, N. 2016. “Deaths, Interventions, Humanitarianism and Human Rights in the Mediterranean 'Migration Crisis"' Mediterranean Politics 21(2):331-35.

Proglio, G. 2018. "Is the Mediterranean a White ItalianEuropean Sea? The Multiplication of Borders in the Production of Historical Subjectivity." Interventions 20(3): 406-22.

Queirolo Palmas, L. 2020. "Back to the Sicilian Landing Sites: Exploring a Borderland Through a Refugee's Gaze.” Journal of Contemporary Ethnography 49(6):835-80.

Repola, L., M. Marazzi, and S. Tilia. 2017. "Constructing and Representing: A New Project for 3D Surveying of Yazılıkaya-Hattuşa." International Archives of the Photogrammetry, Remote Sensing and Spatial Information Sciences, 42-5/W1:395-402. https://doi.org/10.5194/ isprs-archives-XLII-5-W1-395-2017.

Repola, L., J. Leidwanger, and E.S. Greene. 2020. “Digital Models for the Analysis and Enhancement of Hybrid Spaces: Architecture of the Mattanza." International Archives of the Photogrammetry, Remote Sensing and Spatial Information Sciences, 44-M:443-50. https://doi.org/10.5194/ isprs-archives-XLIV-M-1-2020-443-2020.

Ricard-Guay, A. 2018. "Criminalizing Migrants Who Steer the Dinghies in the Mediterranean: A Collateral Effect of Migration Management?" European University Institute Working Paper RSCAS 32. Fiesole.

Rickards, M. 1988. Collecting Printed Ephemera. New York: Abbeville.

Robertson, I.J.M. 2012. "Introduction: Heritage from Below." In Heritage from Below, edited by I.J.M Robertson, 1-28. Farnham: Ashgate.

Royal, J.G., and S. Tusa, eds. 2020. The Site of the Battle of the Aegates Islands at the End of the First Punic War: Fieldwork, Analyses and Perspectives, 2005-2015. BibAr 60. Rome: L'Erma Di Bretschneider.

Ruiz, C. 2019, 14 May. "Fierce Debate Over Christoph Büchel's Venice Biennale Display of Boat That Sank with Hundreds Locked in Hull." The Art Newspaper. www.theartnewspaper.com/news/christoph-buechel.

Salerno, D. 2018. "Memorializing Boat Tragedies in the Mediterranean.: The Case of the Katër I Radës.” In Migration by Boat: Discourses of Trauma, Exclusion, and Survival, edited by L. Mannik, 135-53. New York: Berghahn Books.

Scheele, J. 2012. Smugglers and Saints of the Sahara: Regional Connectivity in the Twentieth Century. Cambridge: Cambridge University Press.

Seitsonen, O.I., V.-P. Herva, and M. Kunnari. 2018. "Abandoned Refugee Vehicles 'In the Middle of Nowhere': Reflections on the Global Refugee Crisis from the Northern Margins of Europe." In The New Nomadic Age: Archaeologies of Forced and Undocumented Migration, edited by Y. Hamilakis, 139-55. Sheffield: Equinox.

Sharpe, C. 2016. In the Wake: On Blackness and Being. Durham: Duke University Press.

Smythe, S.A. 2018. "The Black Mediterranean and the Politics of Imagination.” Middle East Report 286:3-9.

Supernant, K., J.E. Baxter, N. Lyons, and S. Atalay, eds. 2020. Archaeologies of the Heart. Cham, Switzerland: Springer.

Tabak, F. 2008. The Waning of the Mediterranean 1550-1870: A Geohistorical Approach. Baltimore: Johns Hopkins University Press.

Tazzioli, M. 2016. "Border Displacements: Challenging the Politics of Rescue Between Mare Nostrum and Triton.” Migration Studies 4(1):1-19.

Terlizzi, A. 2019. "Border Management and Migration Controls in Italy." In Global Migration: Consequences and 
Responses. RESPOND Working Papers, 2019/17. University of Florence.

Tronto, J.C. 2010. "Creating Caring Institutions: Politics, Plurality and Purpose." Ethics and Social Welfare 4:158-71.

Tyrikos-Ergas, G. 2016. “Orange Life Jackets: Materiality and Narration in Lesvos, One Year After the Eruption of the 'Refugee Crisis.”' In The New Nomadic Age: Archaeologies of Forced and Undocumented Migration, edited by Y. Hamilakis, 121-26. Sheffield: Equinox.

Tzafalias, M. 2016. "Fake Lifejackets Play a Role in Drowning of Refugees." Bulletin of the World Health Organization 94:411-12. www.who.int/bulletin/volumes/ 94/6/16-020616/en/.

Vlachou, M. 2019. "Dividing Issues and Mission-Driven Activism: Museum Responses to Migration Policies and the
Refugee Crisis." In Museum Activism, edited by R.R. Janes and R. Sandell, 47-57. New York: Routledge.

Wilson, J. 2019. “Shipwreck, Without Label.” Performance Research 24(8):69-79.

Wintour, P., L. Tondo, and S. Kirchgaessner. 2018, 11 June. "Southern Mayors Defy Italian Coalition to Offer Safe Port to Migrants." The Guardian. www.theguardian.com/ world/2018/jun/10/italy-shuts-ports-to-rescue-boat -with-629-migrants-on-board.

World Health Organization. 2011. "How Much Water Is Needed in Emergencies?” Technical Notes on DrinkingWater, Sanitation and Hygiene in Emergencies 9. www. who.int/water_sanitation_health/publications/2011/ WHO_TN_09_How_much_water_is_needed.pdf. 